\title{
Investigation of Hydrochemical Parameters of Water Resources in Kamarderaz Anticline Plunge in the Southwest of IRAN
}

Seyed Yahya Mirzaee Aranki ( $\sim$ rogin1394@gmail.com )

Shahid Chamran University of Ahvaz

Sorour Mazrae asl

Shahid Chamran University of Ahvaz

Hosein Karimi Vardanjani

Shahid Chamran University of Ahvaz

\section{Research Article}

Keywords: Oil brine, karstic aquifer, Hydrochemical parameters, Hydrogen sulfide

Posted Date: April 5th, 2021

DOl: https://doi.org/10.21203/rs.3.rs-331133/v1

License: (c) (i) This work is licensed under a Creative Commons Attribution 4.0 International License.

Read Full License 


\section{Investigation of Hydrochemical Parameters of Water Resources 1 in Kamarderaz Anticline Plunge in the Southwest of IRAN 2}

Seyed Yahya Mirzaee Aranki ${ }^{1 *}$, Sorour Mazrae asl ${ }^{2}$, Hosein Karimi Vardanjani ${ }^{3}$

5

6

1 Assistant professor, Department of Geology, Faculty of Earth Science, Shahid Chamran 7 University of Ahvaz, Ahvaz, Iran. Email:

2 M.Sc. Graduated in Hydrogeology, Faculty of Earth Science, Shahid Chamran University 9 of Ahvaz, Ahvaz, Iran. $\quad 10$

3 Ph.D. Graduated in Hydrogeology, Faculty of Earth Science, Shahid Chamran University of 11 Ahvaz, Ahvaz, Iran. 12 13

* Corresponding author: Assistant professor, Department of Geology, Faculty of Earth 16

Science, Shahid Chamran University of Ahvaz, Ahvaz, Iran. Email: rogin1394@gmail.com 17 
Changes in the quality of karstic water resources affected by the proximity to sources of 35 salinity such as evaporate formations and oil brine pose major challenges to such water 36 resources, especially in Khuzestan province, Iran. The karstic water resources of the 37 Kamarderaz anticline plunge in Izeh city in Khuzestan province have hampered water supply 38 management in the region. To determine water quality and the causes of water salinity in the 39 study area, the hydrochemical parameters of the existing water resources were accordingly 40 evaluated. To conduct hydrochemical studies, 21 samples were collected from different water 41 sources of Kamarderaz anticline plunge in 2017-2018. To analyze the garnered data, Piper 42 and Durov diagrams, composite graphs, ion exchange graphs, ion correlation diagrams, 43 salinity source diagrams and ion ratios were used. The results showed that $\mathrm{SO}_{4}{ }^{2-}, \mathrm{Cl}^{-}$, and 44 $\mathrm{Ca}^{2+}$ in the water resources of the study area were likely due to several sources including 45 carbonate minerals, gypsum dissolution, anhydrite, halite as well as oil brine. Besides, $\mathrm{Br} / \mathrm{Cl}, \quad 46$ $\mathrm{I} / \mathrm{Cl}$ ion ratios as well as $\mathrm{Br}-\mathrm{Cl}$ and $\mathrm{SO}_{4}-\mathrm{Cl}$ diagrams revealed the mixing of karstic 47 freshwater with oil brine in the region. The result of TOC analysis also showed that 48 hydrocarbon materials were present in the well of Atabaki (WT). Moreover, elemental sulfur 49 and sulfur isotope analysis showed that the process of thermochemical sulfate reduction or 50 bacterial sulfate reduction in the presence of hydrocarbons produced $\mathrm{H}_{2} \mathrm{~S}$ gas, and eventually 51 penetrated the WT and WH1.

Keywords: Oil brine, karstic aquifer, Hydrochemical parameters, Hydrogen sulfide 53 


\section{Introduction}

Groundwater in karstic aquifers is one of the most important freshwater resources in the world, and in some areas, the only water resources available. $25 \%$ of the world's population supplies their water needs from karstic water resources (ford and Williams 2007). However, 65 social, industrial, and agricultural developments have nowadays led to greater abstraction 66 from groundwater resources, especially karstic aquifer resources, posing significant 67 challenges, including reduced quality and pollution to such water resources. Therefore, water 68 quality assessment and investigation of the origin of contamination of such resources, 69 especially in arid and semi-arid regions, is of great importance (Jalali 2011; Mahmoudi et al. 2017; Sarikhani et al. 2015; Sefie et al. 2018; Wurbs 2011; Zarei et al. 2013). Water quality changes can be affected by human activities or environmental and structural factors 72 associated with water reservoirs. Oil brine infiltration into karstic water resources is one of 73 the contaminants affecting the quality of karstic aquifers (Mirzaee et al. 2019). Various 74 causes have been identified for the salinity of karstic aquifers, including dissolution of 75 evaporate minerals, oil brines, deep water and seawater penetration into these reservoir 76 (Fontes and Matray 1993; Matray et al. 1994; Richter and Kreitler 1991; Rouhi and Kalantari 2018). Depending on the tectonic conditions prevailing in the folded Zagros, the carbonate formations in the region simultaneously host oil and water resources. Such proximity to oil brine, along with the presence of evaporate formations in this part of Zagros, is one of the most important factors in reducing the quality of karstic water resources in this area (Mirzaee et al. 2019).

Investigating and quantifying the salinity-related elements in water resources is thus a 83 necessary and relatively easy task (Dogramaci and Herczeg 2002; Zaporozec 1972) but it is 84 difficult to determine their origin (Panno et al. 1994; Sarikhani et al. 2015). In general, the 85 penetration of hydrocarbons and oil brine in the reservoirs, as well as the presence of 86 evaporative formations, have increased the concentration of ions and the presence of 87 hydrocarbons, especially aromatic hydrocarbons and heavy metals in such reservoirs. In 88 addition to minerals such as $\mathrm{Na}^{+}$and $\mathrm{Cl}^{-}$, oil brine contains significant amounts of $\mathrm{Br}$ and $\mathrm{I} \quad 89$ ions and other secondary ions (Fan et al. 2010).

Hydrochemical evaluations generally use $\mathrm{Na} / \mathrm{Cl}, \mathrm{Br} / \mathrm{Cl}$ and $\mathrm{I} / \mathrm{Cl}$ ion ratios as well as other 91 major $\mathrm{Ca}^{2+}, \mathrm{Mg}^{2+}, \mathrm{Na}^{+}, \mathrm{Cl}^{-}, \mathrm{SO}_{4}{ }^{2-}, \mathrm{HCO}_{3}{ }^{2-}$ ions to distinguish salinity and mixing of saline 92 and fresh water (Cartwright et al. 2006; Fontes and Matray 1993; Mast 1985; Matray et al. 93 1994; Richter and Kreitler 1991; Whittemore and Pollock 1979). The brine from the 94 dissolution of evaporate formations increases the molar ratio of $\mathrm{Na}^{+}$and $\mathrm{Cl}^{-}$ions in water 
(Leonard and Ward 1962). Besides, an increase in the concentration of $\mathrm{SO}_{4}{ }^{2-}$ and $\mathrm{Ca}^{2+}$ due to 96 dissolution of gypsum and anhydrite minerals in these conditions is likely. In addition to the 97 use of ion ratios and salinity indices, the Total Organic Carbon (TOC) index can also be used 98 to investigate the relationship of groundwater to organic matter and hydrocarbons (Chitsazan 99 et al. 2017; Spruill 1988; Thilagavathi et al. 2016). High levels of water-soluble carbon 100 concentration indicates the relationship of water sources with hydrocarbon materials, coal and 101 shale formations (Thilagavathi et al. 2016). Preliminary review of studies on similar topics 102 shows that extensive studies have been already conducted on the interference of groundwater 103 with other sources (e.g., Tellam. 1994; Marie \& Vengosh. 2001; Adams et al. 2001; Kalantari 104 et al. 2007; Karimi \& Moore. 2008; Rezai et al., 2012; Chitsazan et al., 2012; Sarikhani et al. 105 2015; Zega et al. 2015; Reynauld et al 2016; Mahmoudi et al. 2017; Rouhi \& Kalantari. 106 2017; Yang et al. 2019).

Due to the lack of access to surface water flows, Izeh city in the southwestern Iran is heavily 108 dependent on karstic water supplies. Accordingly, to supply part of the city's and its surrounding villages' drinking water in Kamarderaz anticline plunge, five water wells were drilled. During the drilling in the Atabaki area in 2016, two wells encountered $\mathrm{H}_{2} \mathrm{~S}$ gas penetration and increased Ec during drilling, making the wells unexploitable. Considering the high capacity of the aquifer in the anticline plunge, such qualitative changes occurred in this part of the aquifer posed major challenges to supplying the city's drinking water. Given the necessity of water supply for the region, analyses of hydrochemical parameters, geochemical processes, reference ion ratios (Cartwright et al. 2006; Hounslow 1995; Jean et al. 2016; Mahmoudi et al. 2017; Sarikhani et al. 2015; Whittemore and Pollock 1979) graphs of salinity source (Richter and Kreitler 1991) and TOC (Spruill 1988) were performed to investigate the causes of quality changes and also the origin of salinity.

\section{Materials and methods}

\subsection{Study Area}

Kamarderaz anticline is located northeast of Khuzestan province (southwest of Iran) and southwest of Izeh city (Figure 1). The geographical location of the anticline lies between

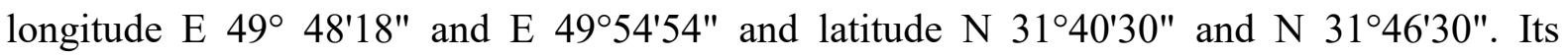
calcareous outcrop area from the northwestern plunge to the southwestern plunge is $15 \mathrm{~km}^{2}$, and the altitude of the northwestern plunge where it meets the plain is $830 \mathrm{~m}$.According to 
average temperature is $21{ }^{\circ} \mathrm{C}$ in the region, and based on meteorological parameters and

\section{Geology and Hydrogeology}

The Zagros orogenic belt in the southwest Iran is one of the richest folded belts in the world. About $8.6 \%$ of the oil reserves and $15 \%$ of the proven gas reservoirs are stored in this belt (Sherkati and Letouzey 2004). The abundance of very rich organic rocks as well as porous production, storage and preservation of hydrocarbon materials available in the Zagros fold belt. This, in turn, makes Zagros zone one of the most oil-rich sedimentary basins in the world (Beydoun et al. 1992; Sherkati and Letouzey 2004). Carbonate sediments in this region not only host oil reservoirs, but also water resources simultaneously, as $23 \%$ of the Zagros extrusive formation are composed of karstic carbonate rocks.

The development of seams and fissures in the Zagros carbonate formation as well as the development of secondary porosities affected by tectonic activity and climatic factors have created many karstic zones in this area of Zagros and have made these formations suitable reservoirs for water storage. The folded Zagros belt shows continuous longitudinal structures such as the mountain frontal fault which are cut and displaced in different parts by transverse structures such as the Izeh fault. There is a clear structural difference between these faults by crossing Izeh's hanging wall to the Dezful embayment, the most important of which is the change in geometry and style of the folds.

Kamarderaz anticline is an asymmetric, one-sided fold which its southwestern edge, affected by tectonic activity in the region, has been severely crushed and completely destroyed except in small sections. The anticline area is very tectonically active and the outcrop formation in this anticline is mainly of Asmari calcareous formation of Oligocene-Miocene age. The Asmari formation is, in turn, composed mainly of lime, dolomite and its lower part includes the marl and anhydrite layers. In the lower part of the Asmari formation, the Pabdeh 154 formation, which is composed of shale, marl and lime sediments with different percentages, belongs to the Paleocene-Eocene time. The Pabdeh formation on both sides restricts the eastern and western edges of the anticline.

Gachsaran evaporate formation consists mainly of evaporate minerals such as gypsum, halite, 
region's formations are shown in Figure 1. The karstic forms in the middle part of the formations are abundant in this anticline. The analysis of the karstic aquifer present in the anticline indicates that the aquifer has three main outcrops in the plunge section, including two springs and Halayejan wells. Total discharge rates of these three adjacent outlets are reported to be approximately 1225 liters per second according to the latest recorded data, though it dried up in 2014.

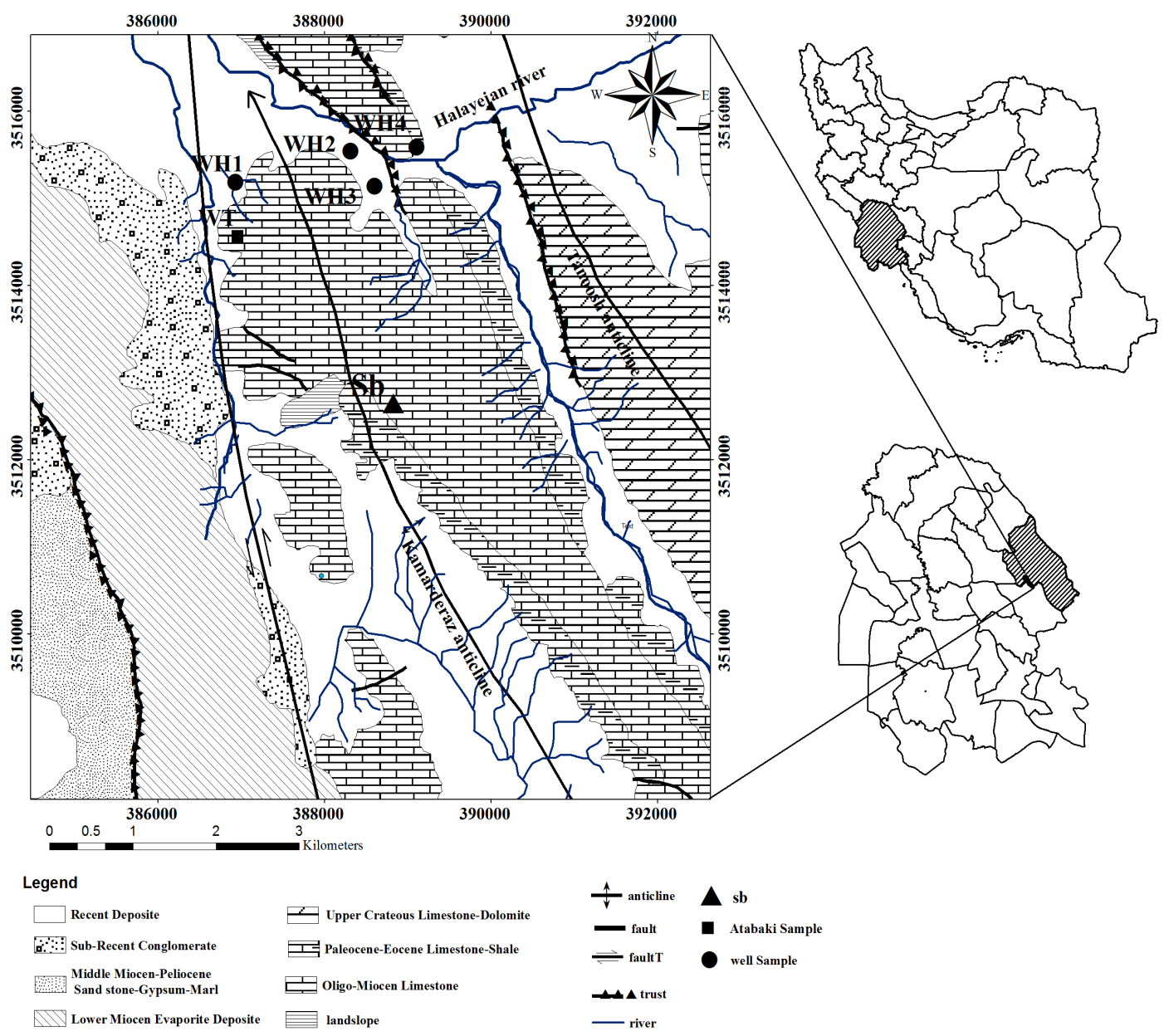

Figure 1: Location map of the study area, sampling sources and formation outcrops in the

\subsection{Sampling and Analysis}

In order to perform hydrochemical studies in a wet and dry period, during four stages, 16 samples of water resources in the study area including: Halayejan wells 1, 2, 3, 4 and two samples of Bibigolmorde spring were taken. Besides, water samples collected during drilling at depths of 69, 97 and 104 m of Atabaki Well were used. The samples were collected in 1- 
liter polyethylene containers and sent to the laboratories after preparation. Analysis of major anions and cations $\left(\mathrm{Ca}^{2+}, \mathrm{Na}^{+}, \mathrm{Mg}^{2+}, \mathrm{K}^{+}, \mathrm{HCO}_{3}{ }^{2-}, \mathrm{SO}_{4}{ }^{2-}, \mathrm{Cl}^{-}\right)$, TDS, Ec was then performed for each sample using spectrophotometer method in Khuzestan Water and Power Organization Laboratory. In turn, the analysis of Br and I ions for WHT, WH2, WH3, WH4, and WT samples was performed by red phenol colorimetric method and catalytic reduction in Aryan Fan Azma Laboratory. Total organic carbon (TOC) was measured in the Fanavar 180 Andishe Kamyar Gostar Laboratory. Elemental sulfur in the depth of $104 \mathrm{~m} \mathrm{WT}$ in was, in turn, measured in Zarazma Laboratory by spectrophotometer method. Sulfur isotopes at a depth of $104 \mathrm{~m}$ WT were determined by mass spectrometry at Isotpe Tech Zrt Laboratory in Hungary. The accuracy of the cation and anion analysis results was then evaluated using the following equation, which reported a data error of less than 0.5 (Equation 1).

Ion Balance $=\frac{\left(\sum \text { Cat }-\sum \text { Ani }\right)}{\left(\sum \text { Cat }+\sum \text { Ani }\right)} \times 100$

Table 1 shows the results of chemical analyzes of samples taken from the sources. The anions 186 and cations in this table are $\mathrm{Ca}^{2+}, \mathrm{Mg}^{2+}, \mathrm{Na}^{+}, \mathrm{K}^{+}, \mathrm{Cl}^{-}, \mathrm{HCO}_{3}{ }^{2-}, \mathrm{SO}_{4}{ }^{2-}$ in units (meq / 1), (mg / 1) TOC (mg / 1) $\mathrm{Br}^{-}, \mathrm{I}^{-},(\mathrm{mg} / \mathrm{l})$ TDS and $(\mathrm{mmho} / \mathrm{cm})$ Ec. Data obtained from hydrochemical analyzes in hydrochemical diagrams, including Piper and Durov diagrams, compound diagrams, ion exchange diagrams, ionic correlation graphs and ion ratios were used to investigate the geochemical factors, the origin of water-soluble ions, origin of salinity in the aquifer studied. The samples were then evaluated in terms of the water quality for drinking and irrigation using data from Schuler and Wilcox diagrams. Moreover, the probability of hydrocarbons in the water resources of the study area was investigated using TOC analysis.

Table 1: Hydrochemical parameters of groundwater samples

\begin{tabular}{lcccccccccccc}
\hline Parameters & $\mathbf{C a}$ & $\mathbf{M g}$ & $\mathbf{N a}$ & $\mathbf{K}$ & $\mathbf{H c 0}$ & $\mathbf{S o}_{4}$ & $\mathbf{C l}$ & $\mathbf{T D S}$ & $\mathbf{E c}$ & $\mathbf{p H}$ & $\mathbf{B r}$ & $\mathbf{I}$ \\
\hline WT-69 & 4.52 & 1.72 & 0.91 & 0.05 & 4.4 & 1.78 & 0.82 & 424 & 642 & 7.8 & - & - \\
WT-97 & 6.45 & 2.69 & 3.62 & 0.06 & 3.23 & 4.99 & 4.4 & 746 & 1130 & 7.8 & - & - \\
WT-104 & 7.08 & 2.57 & 5.84 & 0.07 & 2.95 & 5.61 & 6.8 & 920 & 1438 & 7.9 & 4.91 & 0.018 \\
WH1-07-17 & 5.13 & 1.84 & 2.51 & 0.05 & 3.73 & 2.72 & 2.88 & 550 & 860 & 7.3 & 0.93 & 0.033 \\
WH1-09-17 & 4.37 & 2.43 & 2.51 & 0.04 & 3.22 & 2.87 & 3.06 & 540 & 844 & 7.5 & 0.62 & 0.012 \\
WH1-04-18 & 4.67 & 2.1 & 2.99 & 0.04 & 3.67 & 1.73 & 4.2 & 567 & 914 & 7.5 & - & - \\
WH1-05-18 & 4.53 & 2.28 & 2.6 & 0.04 & 3.71 & 2.5 & 3.04 & 556 & 868 & 7.5 & 0.74 & 0.019 \\
WH2-07-17 & 3.17 & 2.13 & 0.58 & 0.02 & 2.94 & 1.88 & 0.88 & 181.2 & 302 & 7.5 & - & -
\end{tabular}




\begin{tabular}{lllllllllllll} 
WH2-09-17 & 3.12 & 2.37 & 0.62 & 0.02 & 3.37 & 1.64 & 0.92 & 287 & 487 & 7.5 & - & - \\
WH2-04-18 & 3.72 & 0.78 & 0.66 & 0.02 & 3.43 & 0.51 & 1.04 & 285 & 492 & 7.5 & - & - \\
WH2-05-18 & 3.09 & 1.36 & 0.58 & 0.02 & 3.4 & 0.5 & 0.95 & 289 & 490 & 7.4 & 0.97 & 0.044 \\
WH3-07-17 & 3.02 & 1.88 & 0.4 & 0.02 & 3.15 & 1.43 & 0.54 & 246 & 417 & 7.6 & - & - \\
WH3-09-17 & 3.06 & 1.49 & 0.33 & 0.02 & 2.75 & 1.49 & 0.46 & 267 & 404 & 7.7 & - & - \\
WH3-04-18 & 3.38 & 0.65 & 0.58 & 0.02 & 3.53 & 0.4 & 0.88 & 257 & 451 & 6.5 & - & - \\
WH3-05-18 & 3.33 & 1.17 & 0.66 & 0.02 & 3.46 & 0.46 & 1.06 & 321 & 510 & 7.5 & 0.65 & 0.032 \\
WH4-07-17 & 4.75 & 1.77 & 0.84 & 0.02 & 3.14 & 2.93 & 1.11 & 346 & 516 & 7.4 & - & - \\
WH4-09-17 & 2.95 & 1.71 & 1.31 & 0.02 & 2.92 & 1.45 & 1.42 & 358 & 559 & 7.7 & - & - \\
WH4-04-18 & 3.4 & 1.43 & 1.45 & 0.02 & 3.43 & 1.06 & 1.61 & 333 & 584 & 7.4 & - & - \\
WH4-05-18 & 3.29 & 1.46 & 1.45 & 0.03 & 3.17 & 1.3 & 1.56 & 385 & 602 & 7.5 & 0.78 & 0.082 \\
Sb-07-17 & 2.33 & 1.04 & 0.26 & 0.03 & 2.56 & 0.52 & 0.38 & 158 & 273 & 7.7 & - & - \\
Sb-09-17 & 1.46 & 1.34 & 0.18 & 0.02 & 2.17 & 0.38 & 0.25 & 149 & 257 & 7.6 & - & - \\
\hline
\end{tabular}

\section{Results and Discussion}

\subsection{Investigation of chemical properties of groundwater in the study area}

Graphical methods are commonly used to check the quality of water resources, simplify the process of data analysis, and also determine the relationship between data gathered. The most important graphical methods for the analysis of hydrochemical data are: Piper diagram, Wilcox diagram, Schuler diagram and Stiff diagram. Piper diagrams are mainly used to 202 identify hydrochemical facies, water type and geochemical evolution paths in aquifers. Implementation of the hydrochemical data in the Piper diagram showed that the water type in the water resources of $\mathrm{WH} 2, \mathrm{WH} 3, \mathrm{WH} 4, \mathrm{Sb}$ was $\mathrm{Ca}-\mathrm{HCO}_{3}$, while in the $\mathrm{WH} 1$ was $\mathrm{Ca}-\mathrm{Cl}$ during September and May. Investigation of water types in WT at depths of 69, 97 and $104 \mathrm{~m}$ showed that the water type changed from $\mathrm{Ca}-\mathrm{HCO}_{3}$ to $\mathrm{Ca}-\mathrm{SO}_{4}$ and finally to $\mathrm{Ca}-\mathrm{Cl}$. The data scatter analysis on Piper diagram also revealed that the data from WT and WH1 were placed 208 in the mixing zone of this graph (Fig. 2).

The Durov diagram was used to depict the characteristics of groundwater showing different 210 hydrochemical types and processes. Samples from WH2, WH3, WH4, Sb and the 69-meter 211 deep WT sample were located in the first square of the Durov diagram representing karstic freshwater. The WH1 and WH4 July samples as well as the 97 and $104 \mathrm{~m} \mathrm{WT}$ depth samples together with September, April and May WH1 samples were located in the mixing zone of the diagram (Fig. 3). Since the formation of karstic aquifer in the region was of bicarbonate 
type, bicarbonate-calcite type revealed the effect of dissolution of carbonate minerals present in such a formation on the water quality of the aquifer. However, the water type of chlorinated-calcic and sulphated-calcic in some wells and deep in the WT showed the infiltration of chlorine and sulfate from other sources into this karstic aquifer. The dissolution of evaporate minerals including gypsum and halite affected by the presence of the Gs formation (middle Oligocene Evaporate formation) as well as the mixing of aquifer with water containing high amounts of chlorine was likely the cause of these changes occurred in the region.

Piper Diagram

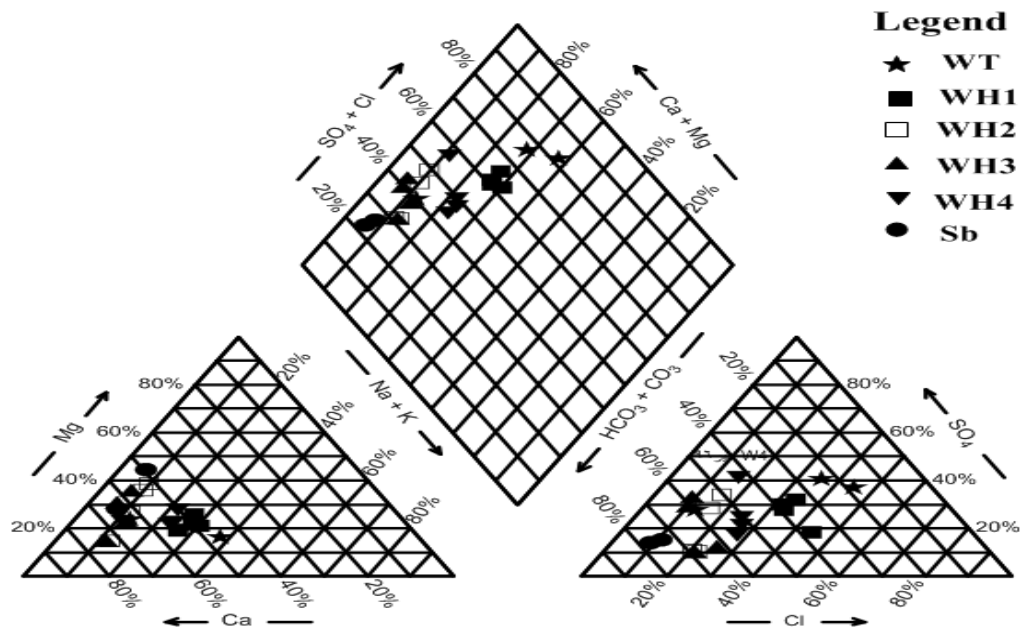

Figure 2. Representation of the studied samples in the Piper diagram

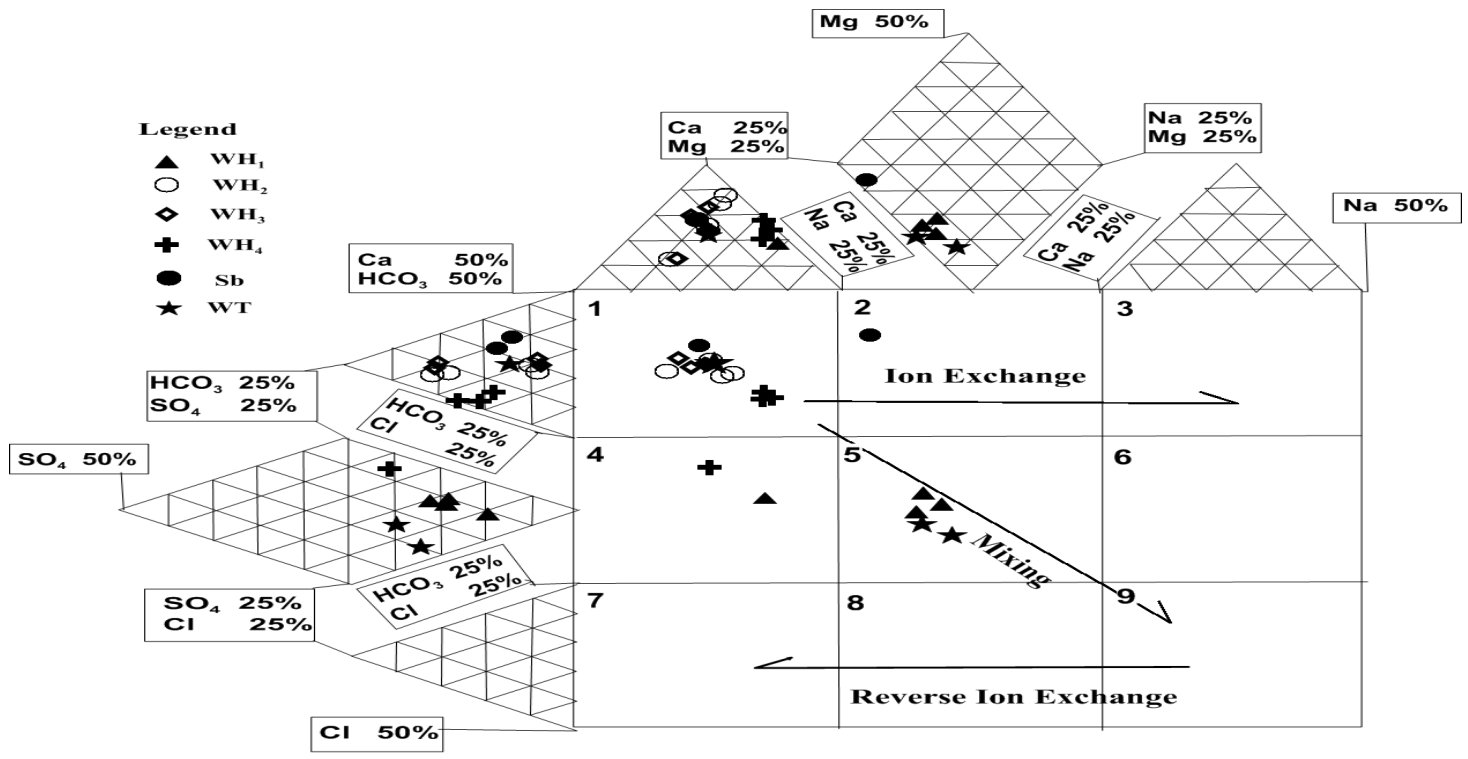

Figure 3 - Representation of samples in the expanded Durov diagram 
High concentration of some water-soluble ions, especially $\mathrm{Na}^{+}$in irrigation water, affects

$\mathrm{SAR}=\mathrm{Na}^{+} /\left(\left(\mathrm{Ca}^{2+}+\mathrm{Mg}^{2+}\right) / 2\right)^{0.5}$

The calculation of sodium absorption index showed that $71.42 \%$ of samples were in C2-S1, repressinting low salinity water almost suitable for agriculture. $28.57 \%$ of the samples were in the C3-S1 range, indicating that these sources had high electrical conductivity, low SAR and generally moderate salinity risk for agriculture (Fig 4).

\subsection{Water quality assessment of the study area for drinking}

Given the importance of water quality for human health, it is important to assess the quality

$\mathrm{Na}, \mathrm{Cl}, \mathrm{SO}_{4}$ : All samples are suitable for drinking except WT which is within the acceptable 


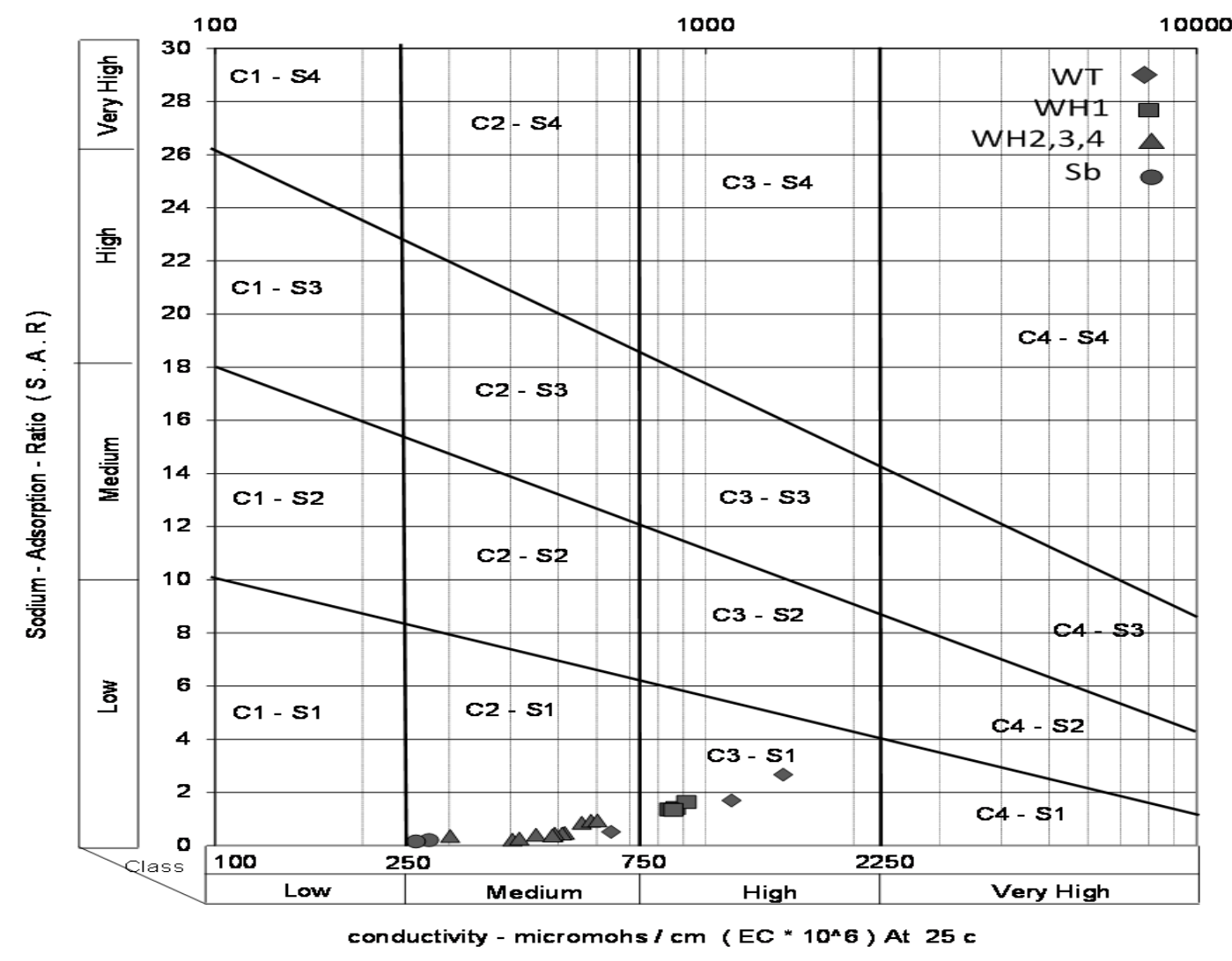

Figure 4. Diagram of salinity risk and alkalinity of agricultural water

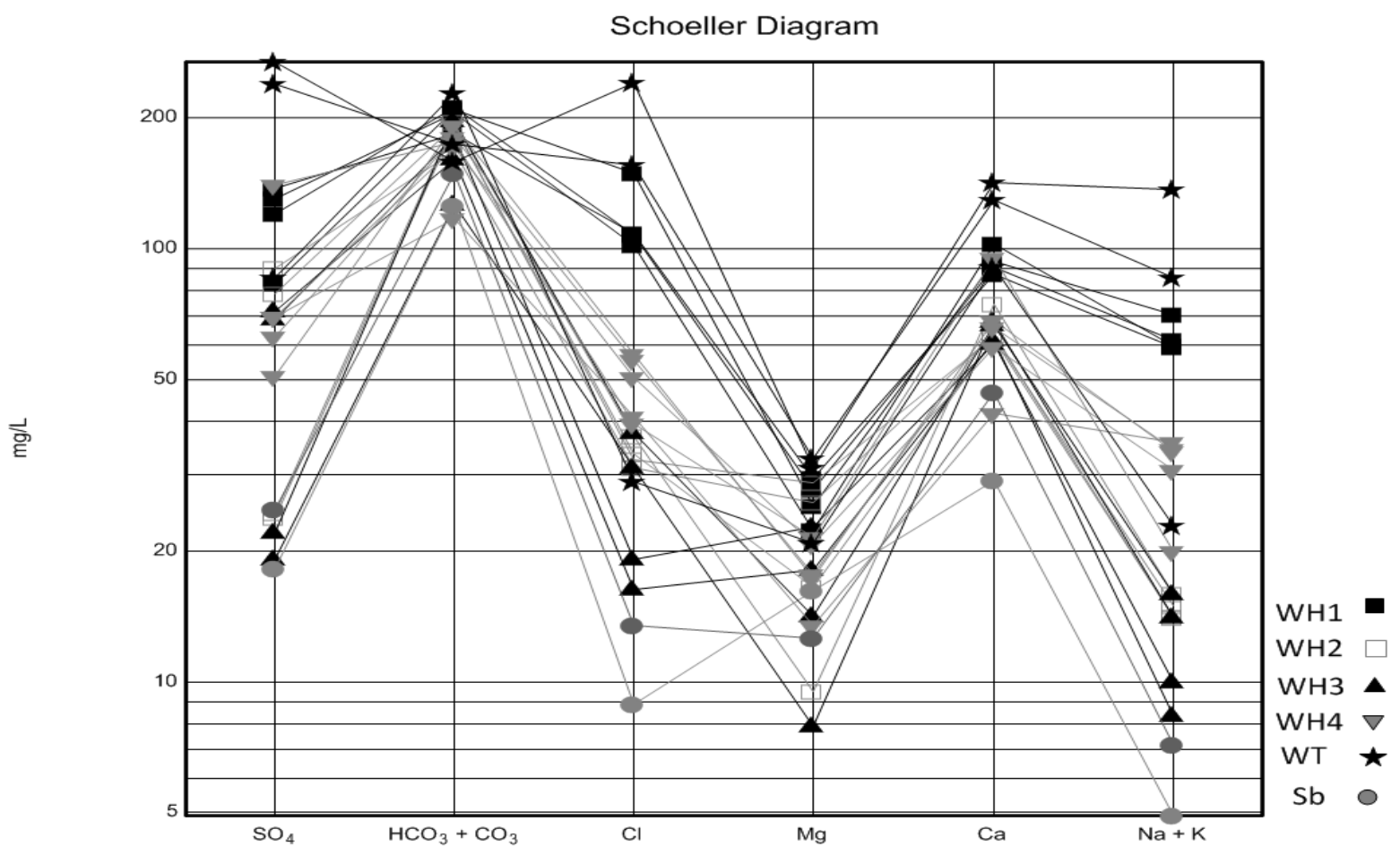

Figure 5. Schuler diagram for water samples in the study area 
In general, chemical processes occur during the interaction of water and rock, including Composite graphs, ion exchange graphs, and ion ratios are commonly used to study the geochemical processes in a region.

\subsection{Composite diagrams}

Composite diagrams are used to determine the source of water and the mixing of water from different sources in the water supply. Figure. 6 presents the composite diagram of $\mathrm{Ca}^{2+}, \mathrm{Mg}^{2}$ ${ }^{+}, \mathrm{Na}^{+}, \mathrm{HCO}_{3}{ }^{2-}, \mathrm{SO}_{4}{ }^{2-}, \mathrm{Cl}^{-}$versus total density of soluble ions (TDI). The good correlation of $\mathrm{Na}^{+}, \mathrm{Cl}^{-}$and $\mathrm{SO}_{4}{ }^{2-}$ ions with TDI indicates the effect of salinity and solute sources resulting from dissolution of evaporate formations on water quality in the study area. The increasing trend of the $\mathrm{Ca}^{2+}$ cation concurrent with the increase in TDI was also due to the correlation of $\mathrm{Mg}^{2}+$ with TDI resulting from dissolution of carbonate minerals including calcite and dolomite in the Asmari calcareous formation (As). Figure 7 shows the composite diagram of $\mathrm{Ca}^{2+}, \mathrm{Na}^{+}, \mathrm{HCO}_{3}{ }^{2-}, \mathrm{SO}_{4}{ }^{2-}$ versus $\mathrm{Cl}^{-}$ions.

Examination of $\mathrm{Na}^{+}$vs. $\mathrm{Cl}^{-}$diagrams as well as $\mathrm{Ca}^{2+}$ versus $\mathrm{SO}_{4}{ }^{2-}$ diagrams showed that the dissolution of gypsum and halite in the area was effective on the water quality of the aquifer. However, the good correlation of calcium cation with chlorine anion revealed that the increase in $\mathrm{Cl}^{-}$was not only influenced by the dissolution of these minerals, but other factors also contributed to changes occurred in the area. This can also be seen in the $\mathrm{Ca}^{2+}$ diagram against $\mathrm{SO}_{4}^{2-}$ (Fig. 8). In this graph, the molar concentration of calcium is much higher than the molar concentration of sulfate, so the distribution of data in this graph is not on a one-toone basis in terms of molar ratio. The distribution of samples on all composite diagrams revealed that the presence of elements such as $\mathrm{Cl}^{-}, \mathrm{Ca}^{2+}$ and $\mathrm{SO}_{4}{ }^{2-}$ in the water resources of the area were likely due to several sources, including dissolution of carbonates, dissolution of 

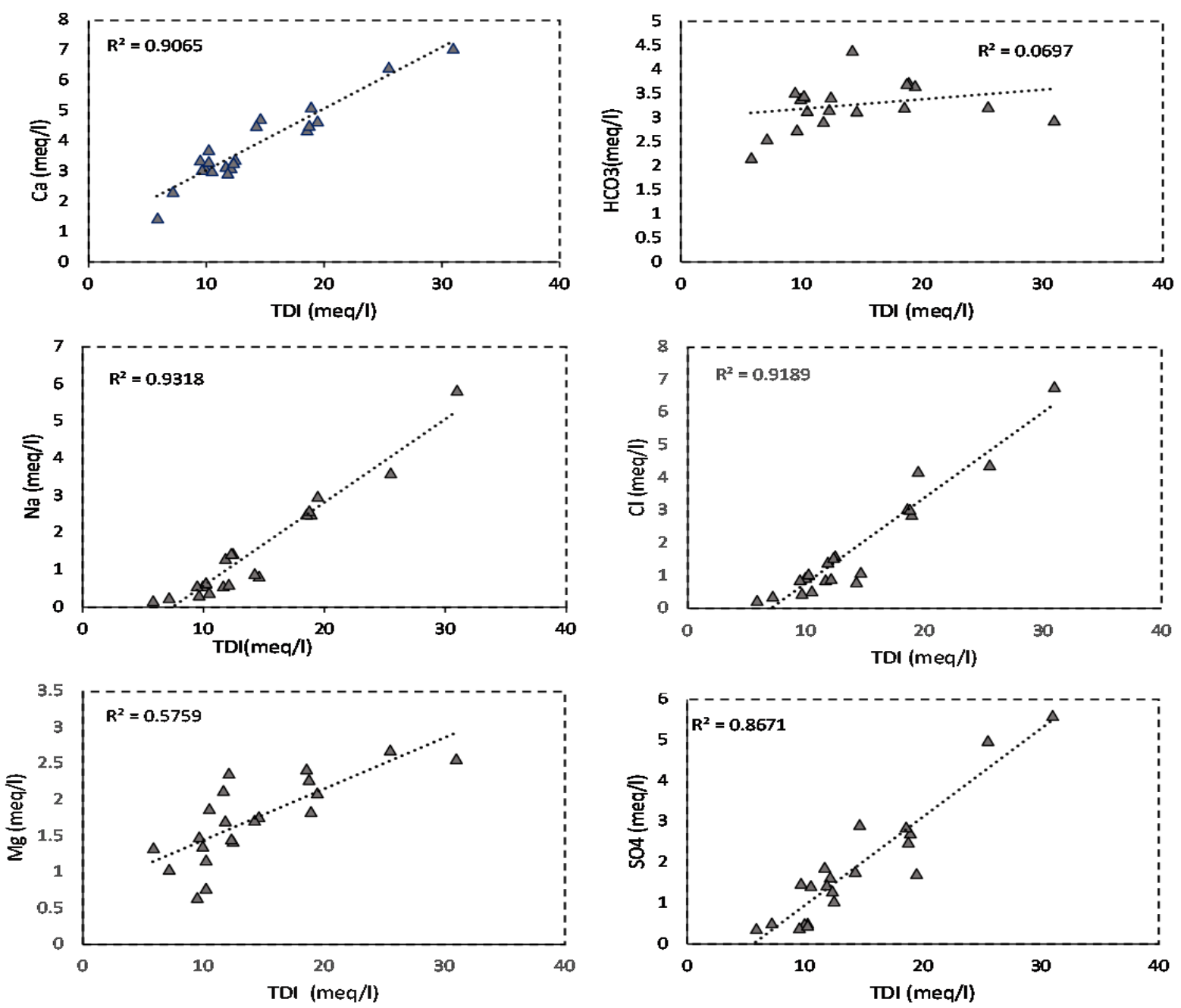

Figure 6. Composite diagrams of the major ions in the samples versus TDI

\subsection{Ion Exchange Charts}

Ion exchange is generally used to express the processes of transfer of ions from the solid phase (minerals) to the soluble phase (water). If the ion exchange is direct, the sodium and potassium in the soil are replaced with calcium and magnesium in the water; while if reversed, the calcium and magnesium in the soil are replaced with sodium and potassium in the water (ion exchange photo) (equation 4).

Ion exchange is possible in aquifers containing montmorillonite clay. Under these conditions, calcium and magnesium are removed from the water and replaced by sodium. In the reverse ion exchange process, free calcium and sodium are replaced by oil brine or seawater. 

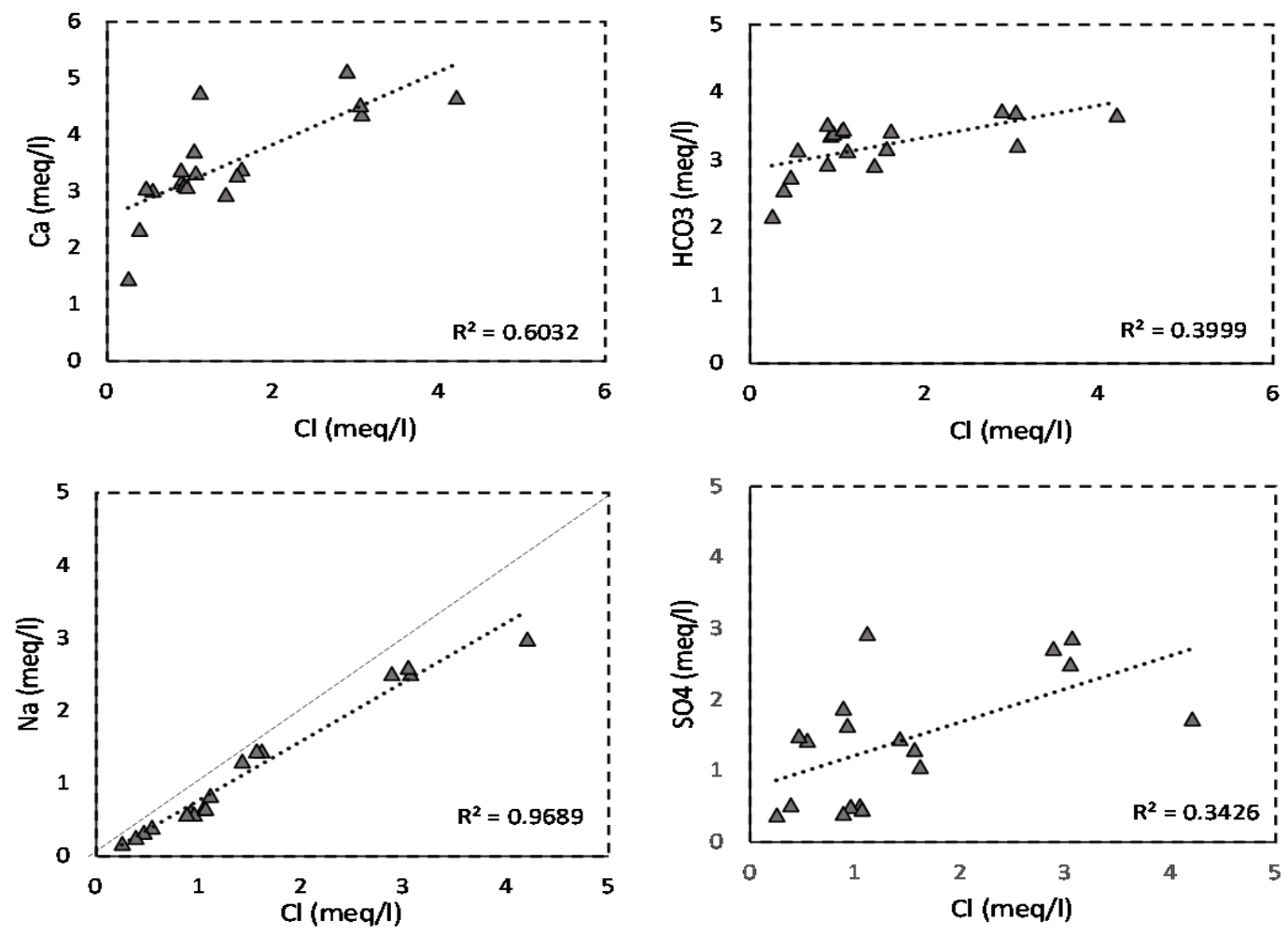

Figure 7. Composite diagram of the major ions versus the chlorine ions

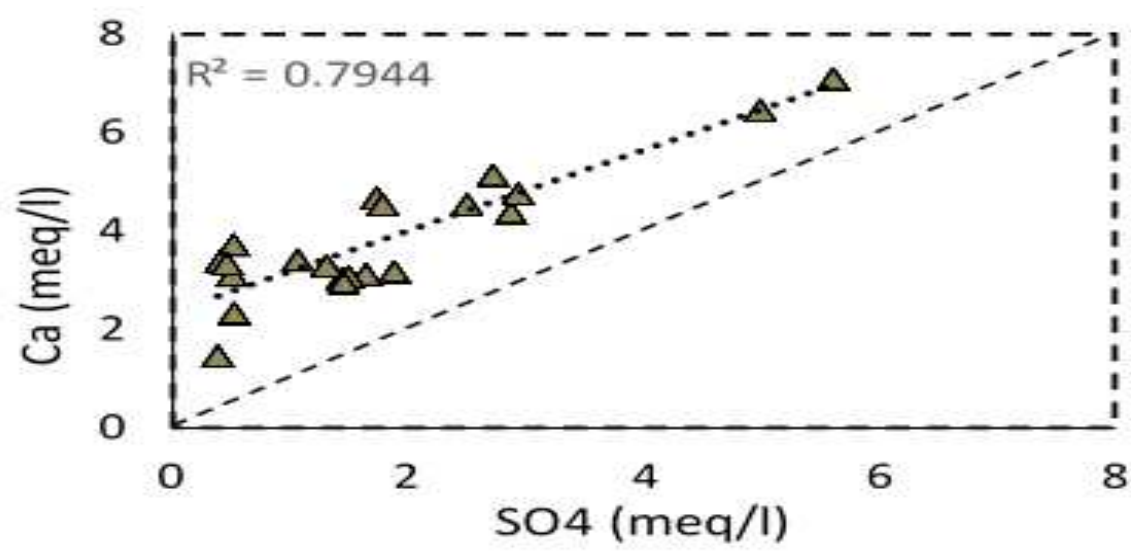

Figure 8. Composite diagram of $\mathrm{Ca}^{2+}$ versus $\mathrm{SO}_{4}{ }^{2-}$

\subsection{Calcium Chart $\left(\mathrm{Ca}^{2+}\right)$ vs. bicarbonate $\left(\mathrm{HCO}_{3}{ }^{2-}\right)$}

The distribution of points on the equilibrium line (1:1) shows the dissolution of carbonates 
exchange. The upper points of the equilibrium line also indicate the process of reverse ion exchange and calcium entry from sources other than carbonate minerals including mixing 309 with brine. Examination of Calcium Chart $\left(\mathrm{Ca}^{2+}\right)$ vs. bicarbonate $\left(\mathrm{HCO}_{3}{ }^{2-}\right)$ showed that the 310 bulk distribution of samples on the equilibrium line was also in the upper part of the line, 311 indicating the dissolution of carbonate minerals for the data on the equilibrium line, and the 312 reverse ion exchange for the samples in the upper part of the line, especially the WH1 and WT samples (Fig. 9).

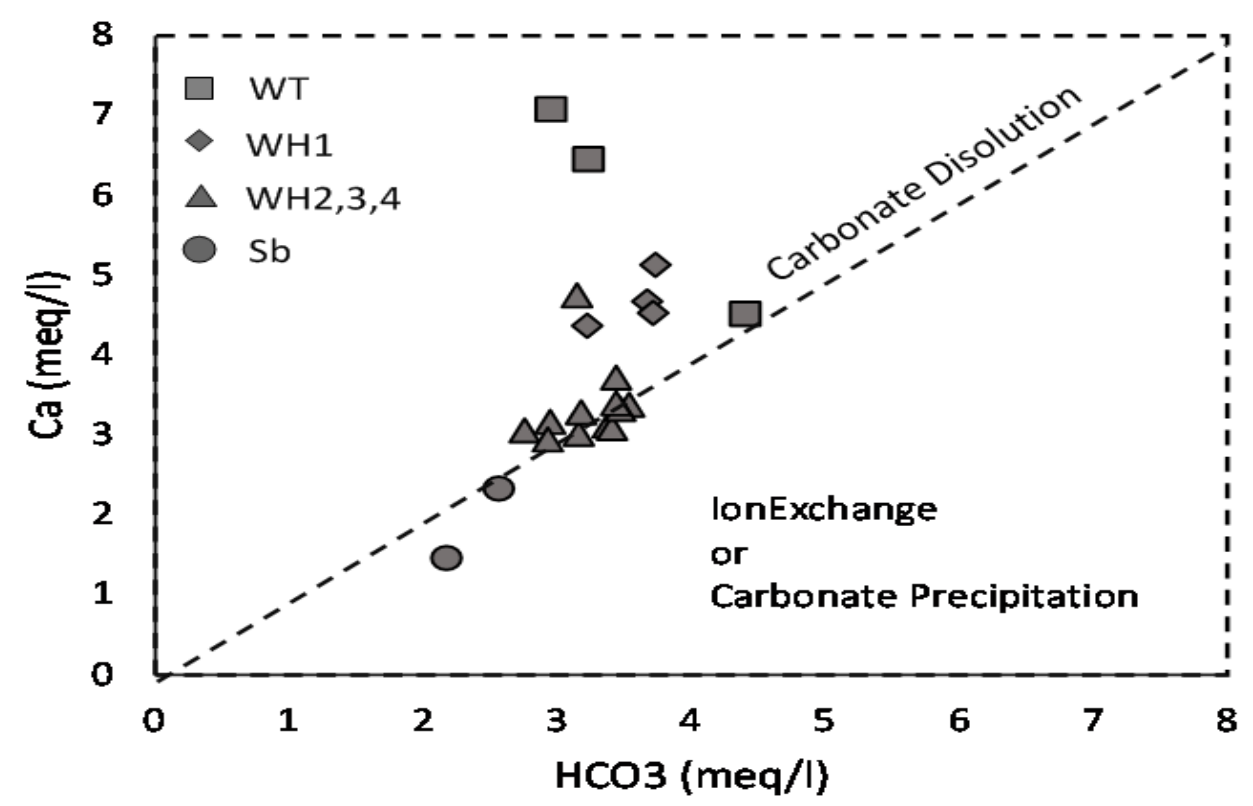

Figure 9. Ion exchange diagrams. Diagram of $\mathrm{Ca}^{2+}$ vs. $\mathrm{HCO}_{3}{ }^{2}$

\subsection{Diagram of $\mathrm{Ca}^{2++} \mathrm{Mg}^{2+}$ vs. $\mathrm{HCO}_{3}{ }^{2}-+\mathrm{SO}_{4}{ }^{2-}$}

In the process of analyzing this graph, samples along the equilibrium line (1:1) showed the 


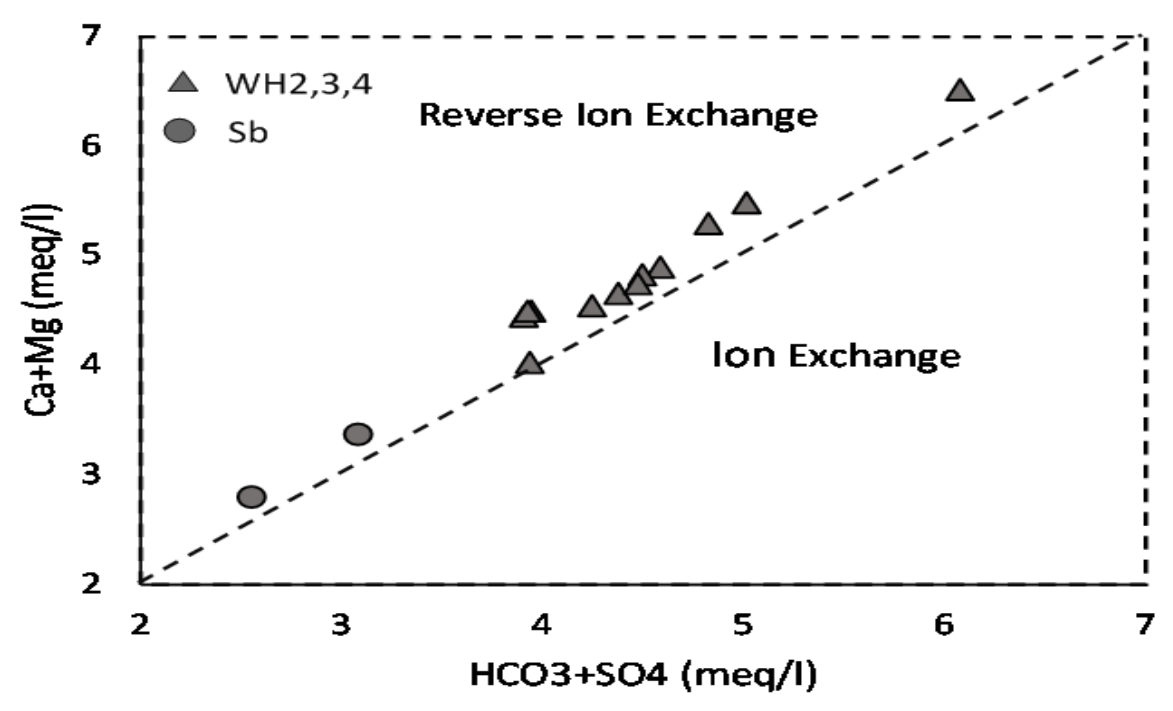

Figure 10. Diagram of $\mathrm{Ca}^{2++} \mathrm{Mg}^{2+}$ vs. $\mathrm{HCO}_{3}{ }^{2-}+\mathrm{SO}_{4}{ }^{2-}$ for $\mathrm{WH} 2, \mathrm{WH} 3, \mathrm{WH} 4, \mathrm{Sb}$

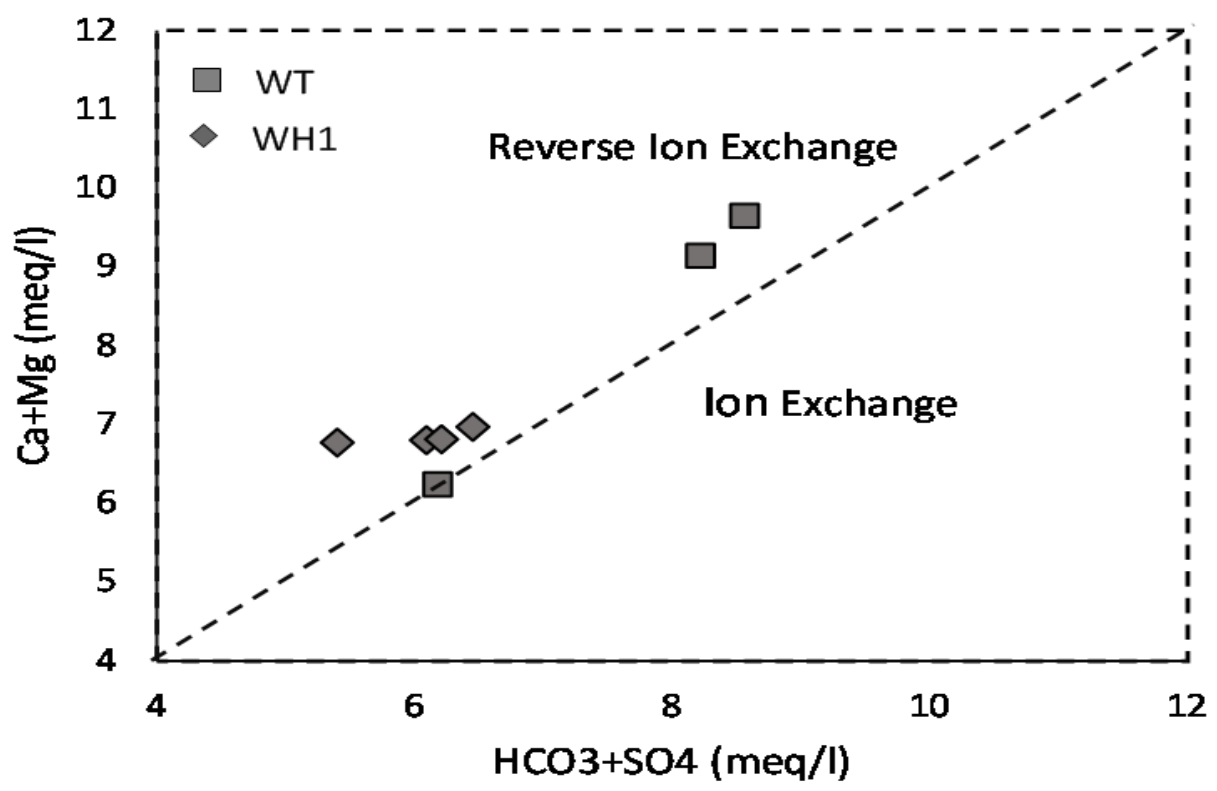

Figure 11. Diagram of $\mathrm{Ca}^{2++} \mathrm{Mg}^{2+}$ vs. $\mathrm{HCO}_{3}{ }^{2-}+\mathrm{SO}_{4}{ }^{2-}$ for $\mathrm{WH} 1$, WT

\subsection{Diagram of $\mathrm{Na}^{+}+\mathrm{k}^{+}-\mathrm{Cl}^{-}$vs. $\mathrm{HCO}_{3}{ }^{2-}+\mathrm{SO}_{4}{ }^{2-}-\mathrm{Ca}^{2+}-\mathrm{Mg}^{2+}$}

The distribution of the data in the $\mathrm{Na}+\mathrm{k}-\mathrm{Cl}$ diagram vs. $\mathrm{Ca}+\mathrm{Mg}-\mathrm{HCO}_{3}-\mathrm{SO}_{4}$ showed that 334 these data were in the upper part of the 1: 1 line and in the reverse ion exchange limit (Fig. 335 12). The positioning of the data in the negative part of the horizontal axis indicated a higher 336 concentration of chlorine than sodium, while the distribution in the positive part of the 
vertical axis was due to the higher concentration of calcium and magnesium compared to

sulfate and bicarbonate. Investigating the causes of this distribution, it can be said that dissolution of halite, gypsum and carbonate minerals alone did not increase the concentration of chlorine, calcium and magnesium in comparison with sodium, sulfate and bicarbonate in

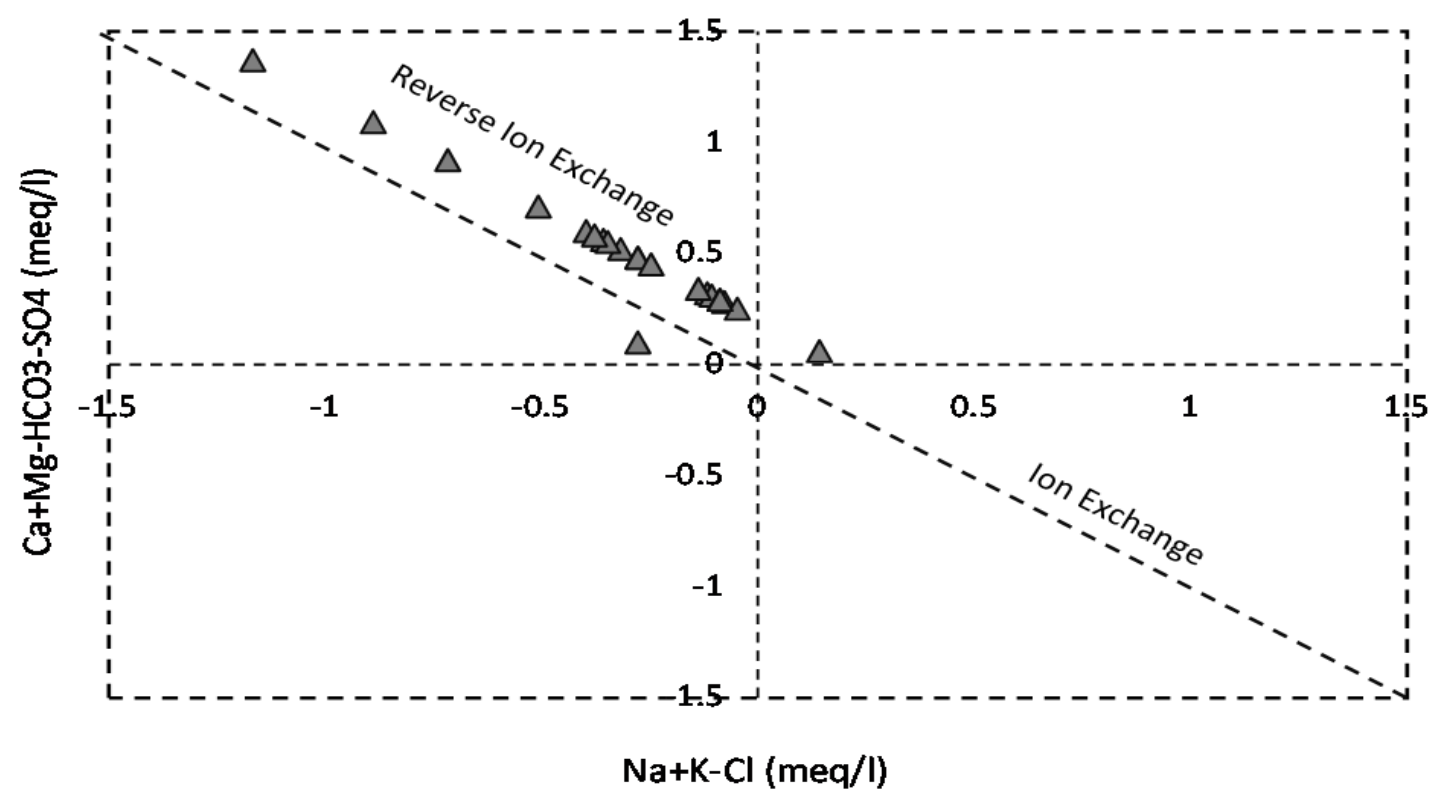

Figure 12. Diagram of $\mathrm{Na}^{+}+\mathrm{k}^{+}-\mathrm{Cl}^{-}$vs. $\mathrm{HCO}_{3}{ }^{2-}+\mathrm{SO}_{4}{ }^{2-}-\mathrm{Ca}^{2+}-\mathrm{Mg}^{2+}$

\subsection{0. $\mathrm{Na} / \mathrm{Cl}$ diagram vs. $\mathrm{EC}$}

The ratio of sodium to chlorine is in the $\mathrm{Na} / \mathrm{Cl}$ diagram versus the vertical axis $\mathrm{EC}$. In the case of halite dissolution, this ratio is one and the data are on the line. The samples above the line are affected by ion exchange, while for the samples in the bottom line the reverse ion exchange occurs (Glover et al. 2012; Jankowski and Acworth 1997). Based on this graph, most of the groundwater samples in the study area are in the reverse ion exchange range (Fig. 13). 


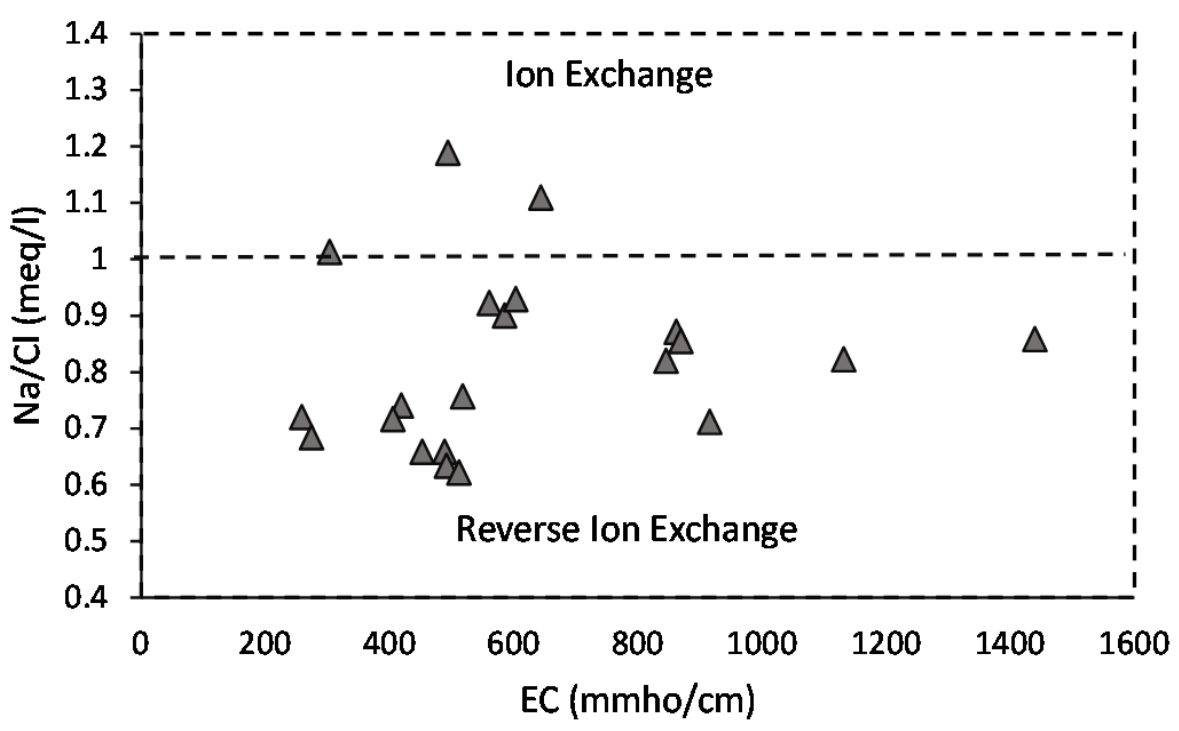

Figure 13. $\mathrm{Na} / \mathrm{Cl}$ diagram vs. EC

\subsection{Ionic ratios of source rock determination}

Ionic ratios are appropriate references for ground water hydrochemical studies to determine the source of solutes. These ratios are influenced by the chemical composition of the watersoluble minerals, and the amount of dissolved minerals are of the next importance. The existence of several different sources for one ion or the chemical changes and interactions occurring due to the presence of different compounds and ions are deemed to cause further complexity and deviation of the ion ratios from their theoretical values (Hounslow 1995). To determine the reference ionic ratios and the source of the minerals as well as their relationship with the geological formations, the hydrochemical data were analyzed according to the Hounslow method, 1995 (Tables 2, 3 and 4).

Table 2. Determination of source rock using ion ratios (Hounslow. 1995)

\begin{tabular}{|c|c|c|}
\hline \multirow{3}{*}{$\mathrm{Na}$} & $>0.5$ & \multirow{2}{*}{$\begin{array}{c}\text { Sodium Source other than Halite-albite,Ion Exchange } \\
\text { Halite Solution }\end{array}$} \\
\hline & $=0$ & \\
\hline & $<0.5 \quad$ TDS $>500$ & Reverse Softening, Seawater \\
\hline \multirow[t]{2}{*}{$\mathrm{Na}+\mathrm{Cl}$} & $<0.5 \quad \mathrm{TDS}<500>50$ & Analysis Error \\
\hline & $<0.5 \quad \mathrm{TDS}<50$ & Rainwater \\
\hline \multirow[b]{2}{*}{$\mathrm{Ca}$} & $=0.5$ & Gypsum dissolution \\
\hline & $<0.5 \quad \mathrm{Ph}<5.5$ & Pyrite Oxidation \\
\hline \multirow[t]{2}{*}{$\overline{\mathrm{Ca}+\mathrm{SO}_{4}}$} & $<0.5 \mathrm{Ph}$ Neutral & Calsium removal-IonExchange or Calcite precipitation \\
\hline & $>0.5$ & Calsium Source other than Gypsum, Carbonate or Silicates \\
\hline \multirow{3}{*}{$\mathrm{Mg}$} & $=0.5$ & Dolomite weathering \\
\hline & $<0.5$ & Limestone-Dolomite weathering \\
\hline & $>0.5$ & Dolomite dissolution, Calcite precipitation or Sea water \\
\hline
\end{tabular}




\begin{tabular}{|c|c|c|}
\hline$\frac{\mathrm{Cl}}{\text { Sum Anion }}$ & $\begin{aligned}>0.8 & \text { TDS }>500 \\
>0.8 & \text { TDS }<100 \\
& <0.8\end{aligned}$ & $\begin{array}{c}\text { Seawater or brine or evaporates } \\
\text { Rainwater } \\
\text { Rock weathering }\end{array}$ \\
\hline$\frac{\mathrm{HCO}_{3}}{\text { Sum Anion }}$ & $\begin{array}{c}>0.8 \\
<0.8 \text { Sulfate high } \\
<0.8 \text { Sulfate low }\end{array}$ & $\begin{array}{c}\text { Silicate or Carbonate weathering } \\
\text { Gypsum dissolution } \\
\text { Seawater brine }\end{array}$ \\
\hline
\end{tabular}

Table 3. Calculated values of reagent ion ratios (Hounslow. 1995)

\begin{tabular}{|c|c|c|c|c|c|c|}
\hline $\mathrm{Na}$ & $\mathrm{Mg}$ & $\mathrm{Ca}$ & $\mathrm{Ca}+\mathrm{Mg}$ & $\mathrm{Cl}$ & $\mathrm{HCO}_{3}$ & آب \\
\hline$\overline{\mathrm{Na}+\mathrm{Cl}}$ & $\overline{\mathrm{Ca}+\mathrm{Mg}}$ & $\overline{\mathrm{Ca}+\mathrm{SO}_{4}}$ & $\mathrm{SO}_{4}$ & $\overline{\text { Sum Anion }}$ & $\overline{\text { Sum Anion }}$ & \\
\hline 0.53 & 0.28 & 0.72 & 3.51 & 0.12 & 0.63 & WT-69 \\
\hline 0.45 & 0.29 & 0.56 & 1.83 & 0.35 & 0.26 & WT-97 \\
\hline 0.46 & 0.27 & 0.56 & 1.72 & 0.44 & 0.19 & WT-104 \\
\hline 0.47 & 0.26 & 0.65 & 2.56 & 0.31 & 0.40 & WH1-07-17 \\
\hline 0.45 & 0.36 & 0.60 & 2.37 & 0.33 & 0.35 & WH1-09-17 \\
\hline 0.42 & 0.31 & 0.73 & 3.91 & 0.44 & 0.38 & WH1-04-18 \\
\hline 0.46 & 0.33 & 0.64 & 2.72 & 0.33 & 0.40 & WH1-05-18 \\
\hline 0.40 & 0.40 & 0.63 & 2.82 & 0.15 & 0.52 & WH2-07-17 \\
\hline 0.40 & 0.43 & 0.66 & 3.35 & 0.16 & 0.57 & WH2-09-17 \\
\hline 0.39 & 0.17 & 0.88 & 8.82 & 0.21 & 0.69 & WH2-04-18 \\
\hline 0.38 & 0.31 & 0.86 & 8.90 & 0.20 & 0.70 & WH2-05-18 \\
\hline 0.43 & 0.38 & 0.68 & 3.43 & 0.11 & 0.62 & WH3-07-17 \\
\hline 0.42 & 0.33 & 0.67 & 3.05 & 0.10 & 0.59 & WH3-09-17 \\
\hline 0.40 & 0.16 & 0.89 & 10.08 & 0.18 & 0.73 & WH3-04-18 \\
\hline 0.38 & 0.26 & 0.88 & 9.78 & 0.21 & 0.69 & WH3-05-18 \\
\hline 0.43 & 0.27 & 0.62 & 2.23 & 0.15 & 0.44 & WH4-07-17 \\
\hline 0.48 & 0.37 & 0.67 & 3.21 & 0.25 & 0.50 & WH4-09-17 \\
\hline 0.47 & 0.30 & 0.76 & 4.56 & 0.26 & 0.56 & WH4-04-18 \\
\hline 0.48 & 0.31 & 0.72 & 3.65 & 0.26 & 0.53 & WH4-05-18 \\
\hline 0.41 & 0.31 & 0.82 & 6.48 & 0.11 & 0.74 & Sb-07-17 \\
\hline 0.42 & 0.48 & 0.79 & 7.37 & 0.09 & 0.78 & $\mathrm{Sb}-09-17$ \\
\hline
\end{tabular}

Table 4. Analysis of ion ratios calculated for the study area based on (Hounslow, 1995)

\begin{tabular}{|c|c|c|c|}
\hline$\frac{\mathrm{Na}}{\mathrm{Na}+\mathrm{Cl}}$ & $<0.5$ & $\mathrm{TDS}>500$ & Reverse ion exchange occurred \\
\hline$\frac{\mathrm{Ca}}{\mathrm{Ca}+\mathrm{SO}_{4}}$ & & $>0.5$ & $\begin{array}{l}\text { There is a source other than } \\
\text { dissolution of gypsum, carbonates } \\
\text { and silicates for calcium ions in } \\
\text { these sources. }\end{array}$ \\
\hline$\frac{\mathrm{Mg}}{\mathrm{Mg}+\mathrm{Ca}}$ & & $<0.5$ & Weathering of calcite and dolomite \\
\hline$\frac{\mathrm{Cl}}{\text { Sum Anion }}$ & & $<0.8$ & Weathering of stone \\
\hline$\frac{\mathrm{HCO}_{3}}{\text { Sum Anion }}$ & & $<0.8$ & dissolution of gypsum \\
\hline
\end{tabular}

Analysis of the ionic ratios of sodium and chlorine indicated a reverse ion exchange in the 
and silicate minerals were not the only source of calcium in these sources. Weathering of

calcite and dolomite as well as dissolution of gypsum in the water resources in the region

\subsection{Diagram of salinity source assessment}

$\mathrm{Na} / \mathrm{Cl}$ weight ratio was used to separate halite dissolution from oilfield brine. If the $\mathrm{Na} / \mathrm{Cl}$

weight ratio was between 0.63 and 0.65 , the salinity factor was due to the dissolution of halite was also found that with increasing depth (97 and $104 \mathrm{~m}$ depth), the difference in concentration of two ions increased due to the increase of $\mathrm{Cl}^{-}$ion concentration. This, in turn,

Table 5. $\mathrm{Na} / \mathrm{Cl}$ weight ratio

\begin{tabular}{cc|cc}
\hline $\mathrm{Na} / \mathrm{Cl}(\mathrm{mg} / \mathrm{l})$ & Water resources & $\mathrm{Na} / \mathrm{Cl}(\mathrm{mg} / \mathrm{l})$ & Water resources \\
\hline 0.6 & WH4-05-18 & 0.42 & WH2-07-17 \\
0.56 & WH1-07-17 & 0.43 & WH2-09-17 \\
0.53 & WH1-09-17 & 0.41 & WH2-04-18 \\
0.46 & WH1-04-18 & 0.39 & WH2-05-18 \\
0.55 & WH1-05-18 & 0.48 & WH3-07-17 \\
0.71 & WT-69 & 0.46 & WH3-09-17 \\
0.53 & WT-97 & 0.42 & WH3-04-18 \\
0.55 & WT-104 & 0.4 & WH3-05-18 \\
0.44 & Sb-07-17 & 0.49 & WH4-07-17 \\
0.46 & Sb-09-17 & 0.59 & WH4-09-17 \\
& & 0.58 & WH4-04-18 \\
\hline
\end{tabular}

Figure 14 shows the samples studied in the diagram of $\mathrm{Na} / \mathrm{Cl}$ weight ratio versus $\mathrm{Cl}^{-}$. The 


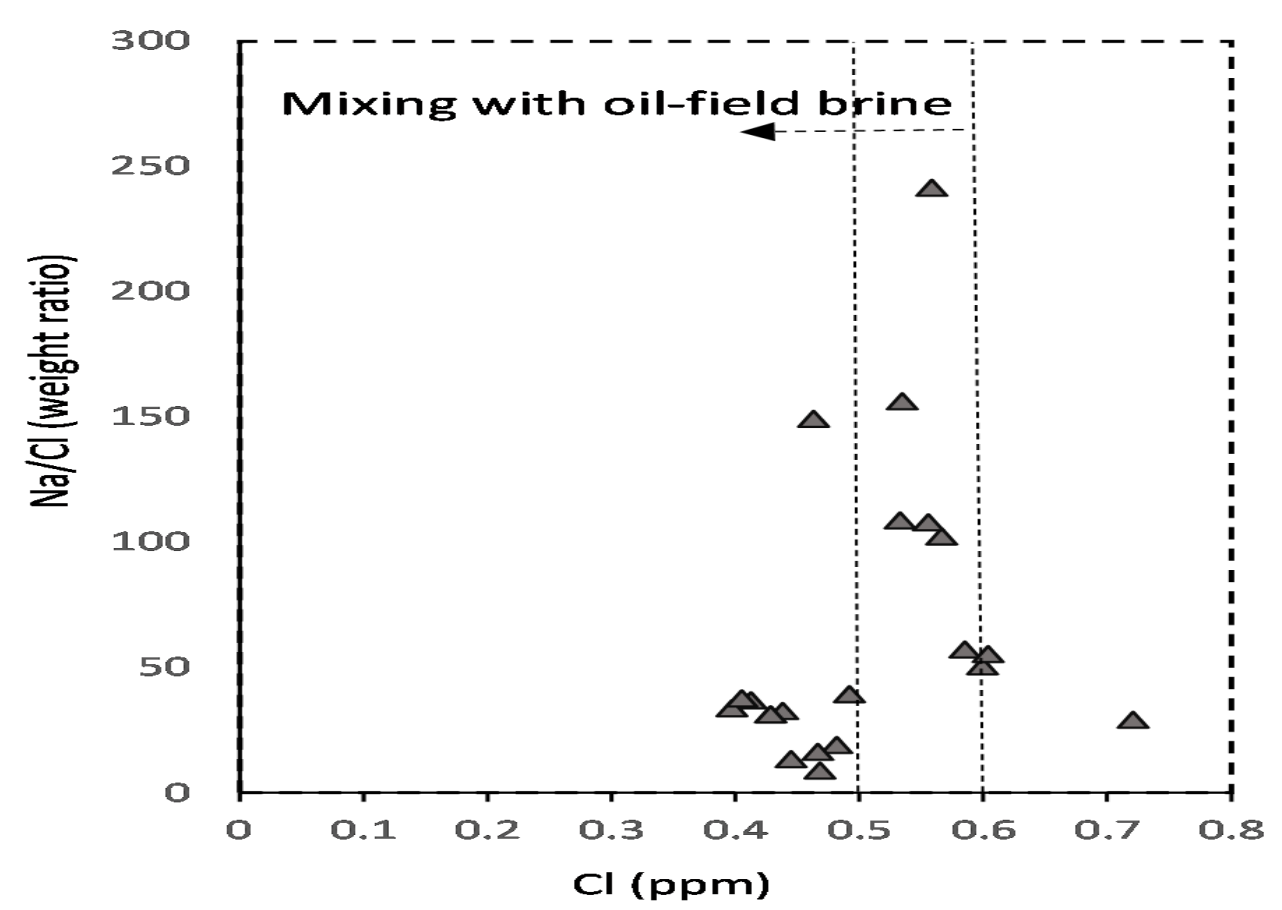

Figure 14. The graph of the $\mathrm{Na} / \mathrm{Cl}$ ratio versus $\mathrm{Cl}^{-}$in terms of weight ratio

In sodium vs. chlorine diagrams in terms of mole ratio, if the samples were below the halite dissolve line (HDL) and deep water mixing line (DWML), the Cl-ion concentration was 398 higher than $\mathrm{Na}^{+}$. Mixing with brine may be the cause for the difference in ratios. In turn, 399 examination of the samples in the chlorine versus sodium diagrams showed that $\mathrm{WH} 1, \mathrm{WH} 2$, 400 WH3, and the WH4 July sample were below the DWML line, indicating the mixing of oil 401 brine with the freshwater sources available (Figures 15 and 16).

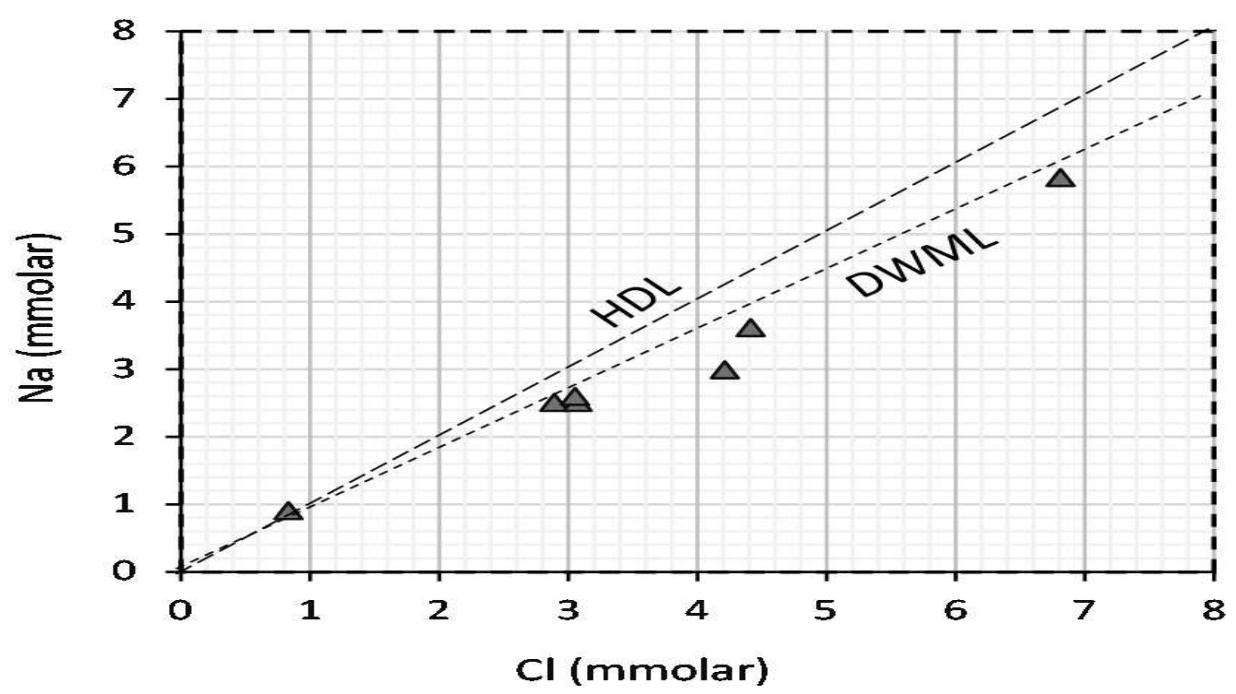

Figure 15. Diagram of $\mathrm{Na}^{+}$ratio to $\mathrm{Cl}^{-}$of WT and WH1 samples 


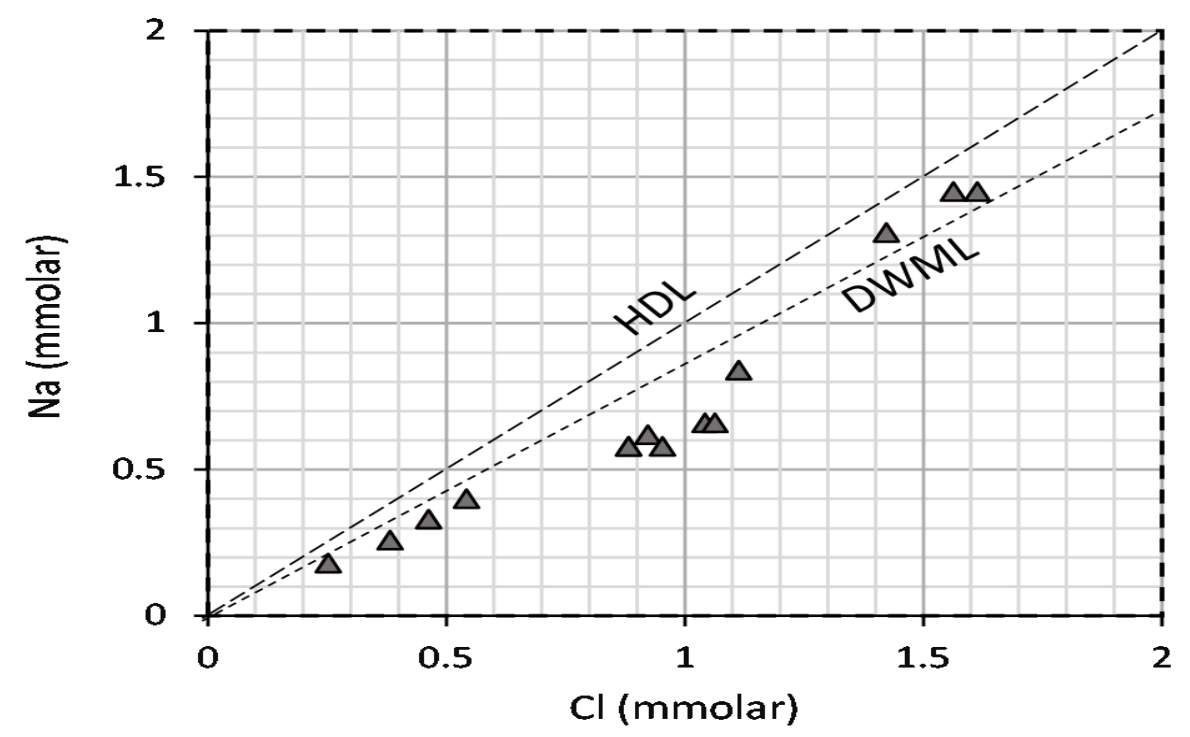

Figure 16. The graph of the $\mathrm{Na}^{+}$ratio to $\mathrm{Cl}^{-}$of samples in $\mathrm{WH} 2, \mathrm{WH} 3, \mathrm{WH} 4, \mathrm{Sb}$

In evaporate formations, halite minerals are often associated with gypsum and anhydrite. In 409 the case of dissolution of evaporate minerals, the molar ratio of calcium to sulfate and sodium to $\mathrm{Cl}^{-}$is equal to one (Richter and Kreitler 1991). Implementation of the data gathered from the study area on the $(\mathrm{Ca}+\mathrm{Mg}) / \mathrm{SO}_{4}$ diagram vs. $\mathrm{Na} / \mathrm{Cl}$ showed that the molar ratio $(\mathrm{Ca}+\mathrm{Mg}) / \mathrm{SO}_{4}$ was higher than one, while the $\mathrm{Na} / \mathrm{Cl}$ molar ratio was lower than one (Fig. 17).

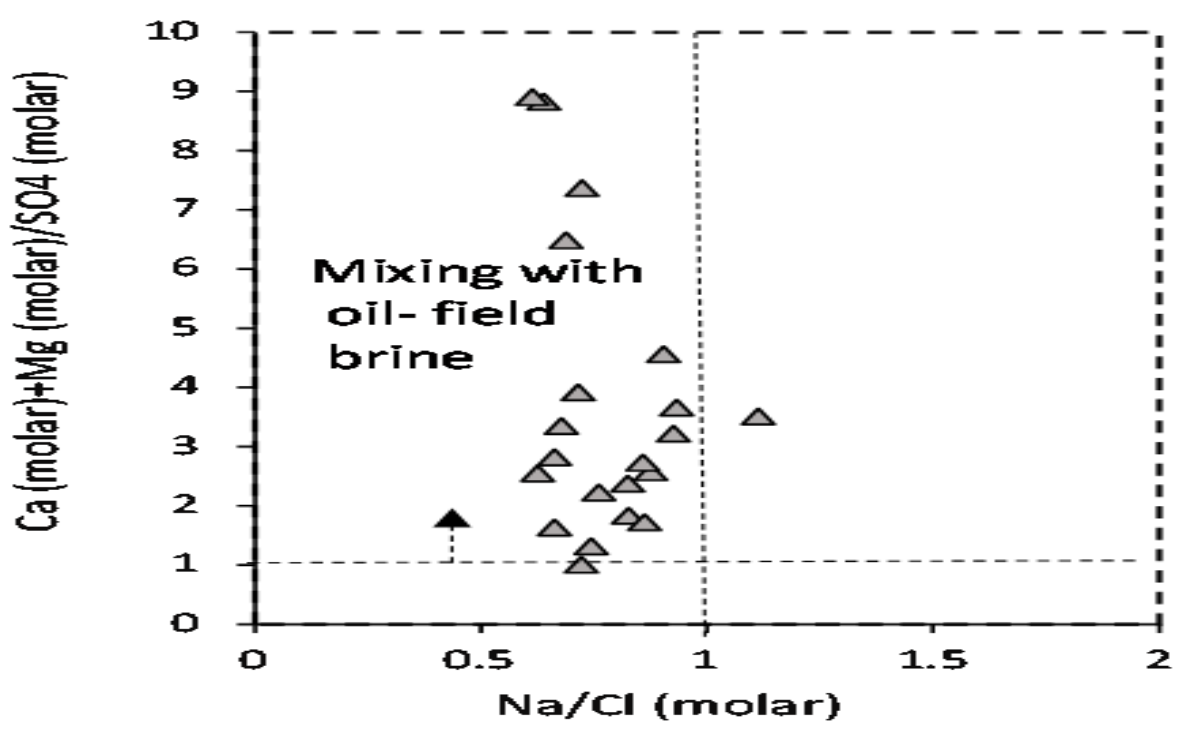

Figure $16(\mathrm{Ca}+\mathrm{Mg}) / \mathrm{SO} 4$ diagram vs. $\mathrm{Na} / \mathrm{Cl}$ 
The $\mathrm{SO}_{4} / \mathrm{Cl}$ ratio is used as an indicator to detect the mixing of freshwater with oil brine

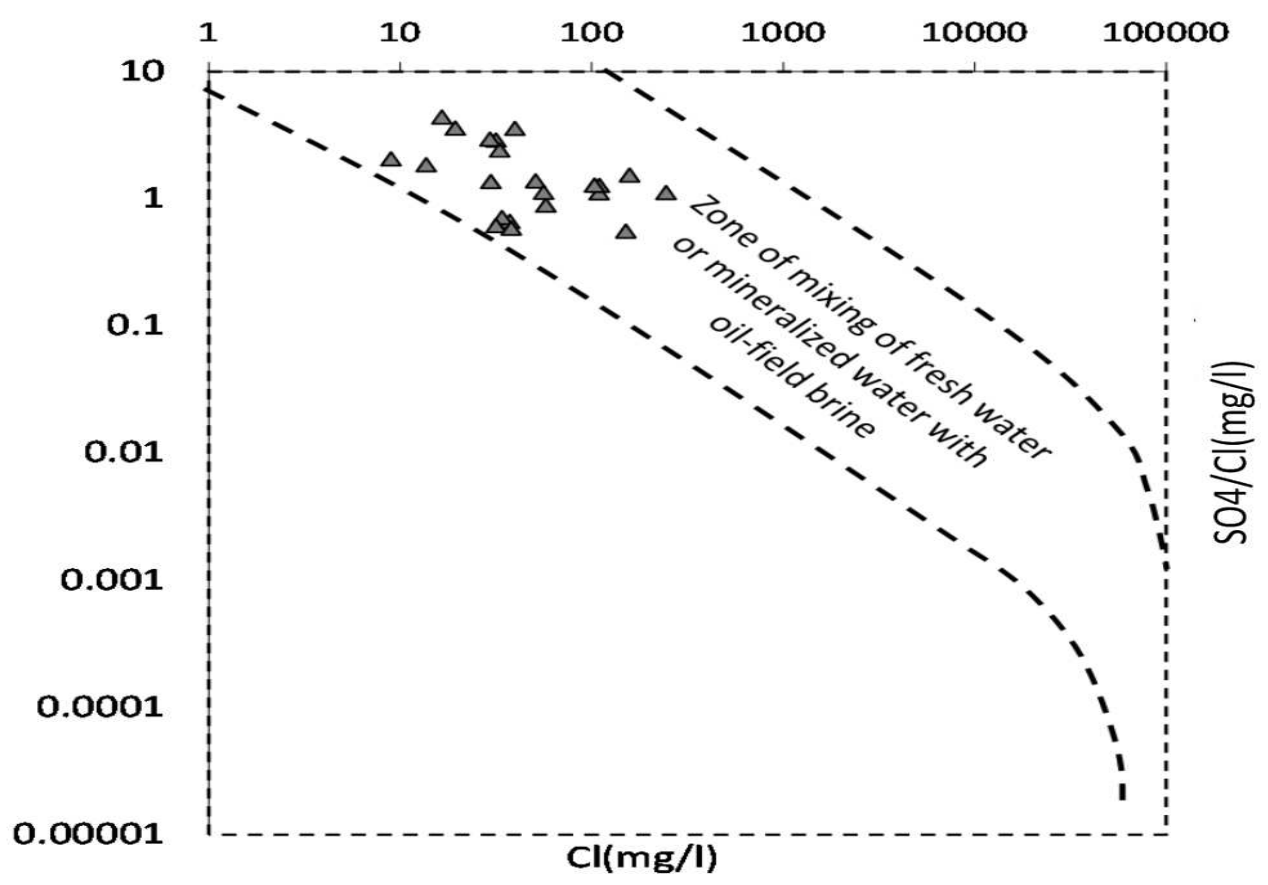

Figure 18. Diagram of the ion ratio of $\mathrm{SO}_{4} / \mathrm{Cl}$ to $\mathrm{Cl}^{-}$in terms of weight ratio

\subsection{5. $\mathrm{Br} / \mathrm{Cl}$ and $\mathrm{I} / \mathrm{Cl}$ ratios}

$\mathrm{Br}^{-}$and $\mathrm{I}^{-}$are used as the most important elements in the investigation of groundwater mixing reservoirs, the concentration of $\mathrm{Br}^{-}$and $\mathrm{I}^{-}$ions and their ratios to $\mathrm{Cl}^{-}$ions was measured in 
to their mixing with the brine of the oil fields in the region (Cartwright et al. 2006;

Table $6 . \mathrm{Br} / \mathrm{Cl}$ and $\mathrm{I} / \mathrm{Cl}$ ratios

\begin{tabular}{ccc}
\hline $\begin{array}{c}\mathbf{I} / \mathbf{C l} \\
\mathbf{M g} / \mathbf{l}\end{array}$ & $\begin{array}{c}\mathbf{B r} / \mathbf{C l} \\
\mathbf{M g} / \mathbf{l}\end{array}$ & $\begin{array}{c}\text { Water } \\
\text { resources }\end{array}$ \\
\hline 0.0013 & 0.028 & $\mathbf{W H 2 - 0 5 - 1 8}$ \\
0.00084 & 0.0172 & $\mathbf{W H 3 - 0 5 - 1 8}$ \\
0.0014 & 0.0141 & $\mathbf{W H 4 - 0 5 - 1 8}$ \\
0.0032 & 0.0091 & WH1-07-17 \\
0.00011 & 0.0057 & WH1-09-17 \\
0.00017 & 0.00686 & WH1-09-18 \\
0.000074 & 0.020 & WT-104 \\
\hline
\end{tabular}

Examination of the ratio of these elements in the studied water samples showed that all 19).

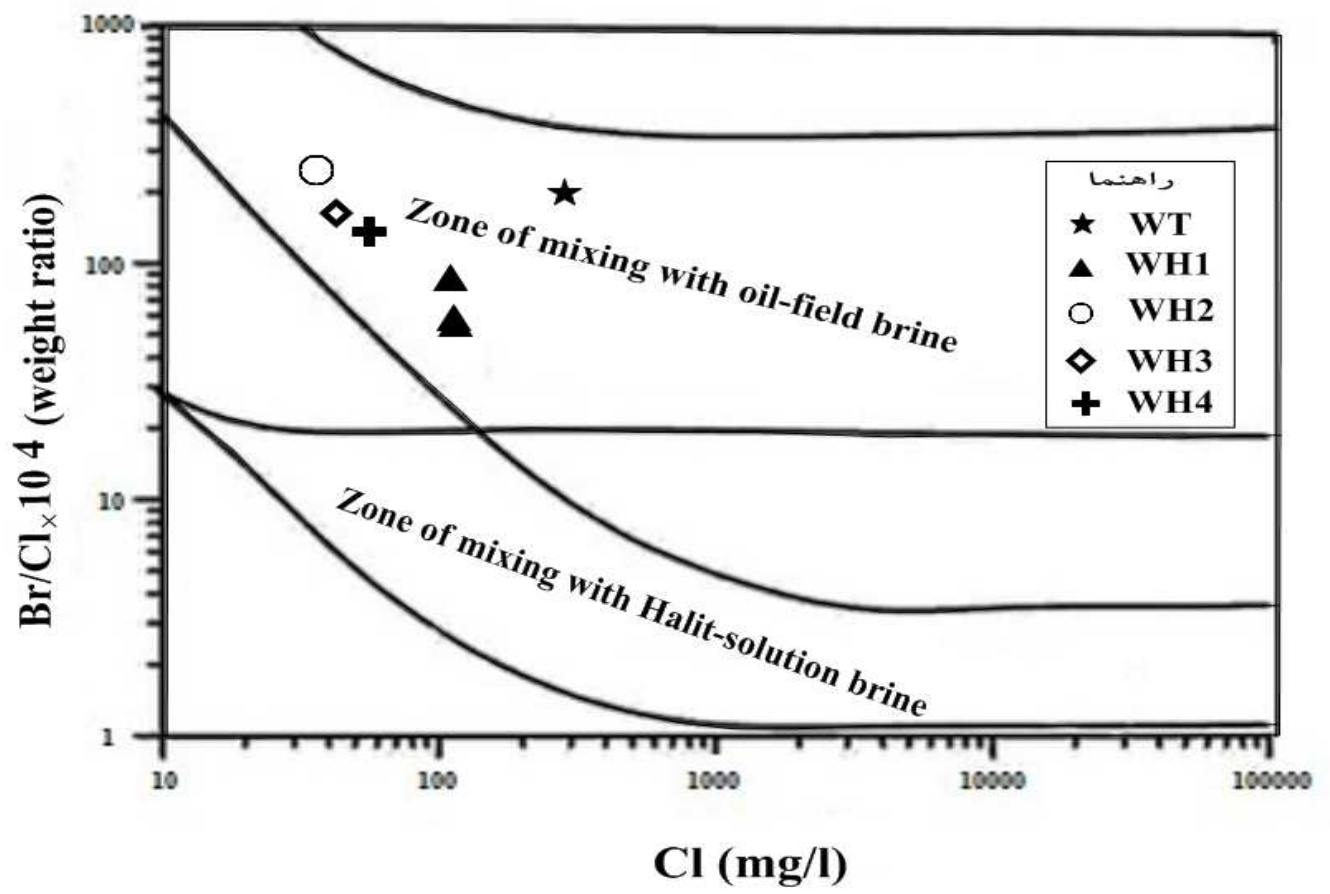

Figure $19 . \mathrm{Br} / \mathrm{Cl}$ ratio diagram versus $\mathrm{Cl}$ in weight ratio 
Total organic carbon is an indicator for detecting contamination of water resources with organic matter. If the concentration of TOC in water is more than $2 \mathrm{mg} / \mathrm{lit}$, it indicates contamination with hydrocarbons (Chitsazan et al. 2017; Spruill 1988). TOC index was used to study the penetration of hydrocarbons in the region's water resources. The TOC analysis in the WT sample showed that the concentration of this parameter is $23.2 \mathrm{mg} / \mathrm{L}$, indicating the

\subsection{Sulfur}

As one of the main problems in the development of Kamarderaz anticline aquifer is the outflow of $\mathrm{H}_{2} \mathrm{~S}$ and the bad smell of water coming out of the wells in the area, the factors related to this phenomenon were studied in the region. Sulfur is the tenth most abundant element in the world and the 14th most abundant in the Earth's crust. Therefore, it is possible to know the origin of minerals containing sulfur and its derivatives by using sulfur isotopes (Seal 2006). Elemental sulfur can be deposited as a yellow sediment as a result of $\mathrm{H}_{2} \mathrm{~S}$ emissions.

Analysis of the $104 \mathrm{~m}$ depth sample of WT showed high levels of elemental sulfur (78.98 $\mathrm{mg} / \mathrm{l})$ in the water of this well. Therefore, to investigate the involvement of hydrocarbons in the production of $\mathrm{H}_{2} \mathrm{~S}$ gas and the deposition of sulfur in this well, the analysis of $\delta^{34} \mathrm{~s}$ 466 isotope in sulfate was performed on the water sample of the well. The sulfur isotope content in this study was estimated to be +19.3 per thousand. According to the region's formations and the results of sulfur isotope analysis as well as elemental sulfur, various mechanisms were identified for $\mathrm{H}_{2} \mathrm{~S}$ production in the region, including bacterial sulfate reduction, thermochemical sulfate reduction, and the contact of anhydrite with hydrocarbon materials. important role in $\mathrm{H}_{2} \mathrm{~S}$ production (Saberi 2019; Worden and Smalley 1996). This process occurs at temperatures above $127^{\circ} \mathrm{C}$. In this process, sulfur and $\mathrm{H} 2 \mathrm{~S}$ gas are produced by the reaction of anhydrite and hydrocarbon (Eq. 3). In addition to the thermochemical reduction of sulfate, water-soluble sulfate can produce $\mathrm{H}_{2} \mathrm{~S}$ gas by a bacterial sulfate reduction process at temperatures below $80^{\circ} \mathrm{C}$ (Eq. 4) (Heydari 1997; Khatib and Salanitro 1997). Other mechanisms of $\mathrm{H}_{2} \mathrm{~S}$ production include the contact of hydrocarbons with sulfated layers such 
production (Eq. 5). In this mechanism, sulfate reducing bacteria derive their energy from of the above processes.

$2 \mathrm{CaSO}_{4}+\mathrm{C}_{2} \mathrm{H}_{6} \rightarrow 2 \mathrm{CaCO}_{3}+\mathrm{S}+\mathrm{H}_{2} \mathrm{~S}+2 \mathrm{H}_{2} \mathrm{O}$

$\mathrm{SO}_{4}(\mathrm{aq})+$ Hydrocarbone $\rightarrow \mathrm{H}_{2} \mathrm{~S}+\mathrm{CO}_{2}+\mathrm{CaCO}_{3}$

$\mathrm{SO}_{4}$ (solid)+Hydrocarbone $\rightarrow \mathrm{H}_{2} \mathrm{~S}+\mathrm{CO}_{2}+\mathrm{H}_{2} \mathrm{O}$

\section{Conclusions}

Applying the results of chemical analysis of the samples in the Piper and Durov diagrams 
and isotope $\delta^{34} \mathrm{~S}$ in sulfate showed that the mechanism of bacterial reduction of water-soluble

sulfate or sulfate present in evaporate minerals was more likely to produce $\mathrm{H}_{2} \mathrm{~S}$ gas in the

\section{Conflict of Interests}

Authors have no conflict of interests.

Acknowledgments

The authors are to acknowledge the Department of Geology, Faculty of Earth Science, 521

Shahid Chamran University of Ahvaz, Ahvaz, Iran for their cooperation in obtaining the 522 required data.

Disclosure statement

No potential conflict of interest was reported by the authors.

This study was originally approved by the Shahid Chamran University of Ahvaz, Ahvaz, Iran.

'Not applicable' for that specific section.

-Consent to Publish

'Not applicable' for that specific section. 
Study concept, design and critical revision of the manuscript for important intellectual

\section{-Funding}

This work was financially supported by Shahid Chamran University of Ahvaz, Ahvaz, Iran.

\section{-Competing Interests}

persons who meet authorship criteria are listed as authors, and all authors certify that they

have participated sufficiently in the work to take public responsibility for the content,

\section{Category 1}

- Conception and design of study: Seyed Yahya Mirzaee Aranki, Sorour Mazrae asl, Hosein

- acquisition of data: Seyed Yahya Mirzaee Aranki

- analysis and/or interpretation of data: Sorour Mazrae asl, Hosein Karimi Vardanjani

\section{Category 2}

- Drafting the manuscript: Seyed Yahya Mirzaee Aranki, Sorour Mazrae asl, Hosein Karimi

- revising the manuscript critically for important intellectual content: Seyed Yahya Mirzaee

\section{Category 3}

Approval of the version of the manuscript to be published (the names of all authors must be

Seyed Yahya Mirzaee Aranki, Sorour Mazrae asl, Hosein Karimi Vardanjani 


\section{References}

Beydoun, Z., Clarke, M. H., \& Stoneley, R. (1992). Petroleum in the Zagros basin: a late tertiary foreland basin overprinted onto the outer edge of a vast hydrocarbon-rich paleozoic-mesozoic passive-margin shelf: chapter 11.

Cartwright, I., Weaver, T. R., \& Fifield, L. K. (2006). Cl/Br ratios and environmental isotopes as indicators of recharge variability and groundwater flow: an example from the southeast Murray Basin, Australia. Chemical Geology, 231(1-2), 38-56.

Chitsazan, M., Shacheri, S., Mirzaee, S., \& Aboudi, S. (2017). assessment of karstic aquifer water resources ase study Garuo karstic spring located in eastern of Khuzestan. journal of Advanced Applied Geology, 6575.

Claypool, G. E., Holser, W. T., Kaplan, I. R., Sakai, H., \& Zak, I. (1980). The age curves of sulfur and oxygen isotopes in marine sulfate and their mutual interpretation. Chemical geology, 28, 199-260.

Dogramaci, S. S., \& Herczeg, A. L. (2002). Strontium and carbon isotope constraints on carbonate-solution interactions and inter-aquifer mixing in groundwaters of the semi-arid Murray Basin, Australia. Journal of Hydrology, 262(1-4), 50-67.

Fan, Q., Ma, H., Lai, Z., Tan, H., \& Li, T. (2010). Origin and evolution of oilfield brines from Tertiary strata in western Qaidam Basin: Constraints from $87 \mathrm{Sr} / 86 \mathrm{Sr}, \delta \mathrm{D}, \delta 18 \mathrm{O}, \delta 34 \mathrm{~S}$ and water chemistry. Chinese Journal of Geochemistry, 29(4), 446-454.

Fontes, J. C., \& Matray, J. (1993). Geochemistry and origin of formation brines from the Paris Basin, France: 2. Saline solutions associated with oil fields. Chemical Geology, 109(1-4), 177-200.

ford, \& Williams (2007). Karst Hydrogeology and Geomorphology. John Wiley \& Sons Ltd, Chichester.

Freeman, J. T. (2007). The use of bromide and chloride mass ratios to differentiate salt-dissolution and formation brines in shallow groundwaters of the Western Canadian Sedimentary Basin. Hydrogeology Journal, 15(7), 1377-1385.

Glover, E., Akiti, T., \& Osae, S. (2012). Major ion chemistry and identification of hydrogeochemical processes of ground water in the Accra Plains. Geoscience, 50, 10279-10288.

Han, D., Song, X., Currell, M. J., Yang, J., \& Xiao, G. (2014). Chemical and isotopic constraints on evolution of groundwater salinization in the coastal plain aquifer of Laizhou Bay, China. Journal of Hydrology, $508,12-27$.

Heydari, E. (1997). The role of burial diagenesis in hydrocarbon destruction and H2S accumulation, Upper Jurassic Smackover Formation, Black Creek Field, Mississippi. AAPG bulletin, 81(1), 26-45.

Hounslow, A. (1995). Water quality data: analysis and interpretation: CRC press.

Jalali, M. (2011). Nitrate pollution of groundwater in Toyserkan, western Iran. Environmental Earth Sciences, 62(5), 907-913.

Jankowski, J., \& Acworth, R. I. (1997). Impact of debris-flow deposits on hydrogeochemical processes and the developement of dryland salinity in the Yass River Catchment, New South Wales, Australia. Hydrogeology journal, 5(4), 71-88.

Jean, J.-S., Liao, L., Kar, S., Liu, C.-C., \& Li, Z. (2016). Hydrochemistry of hot springs in geothermal fields of central, northern, and northeastern Taiwan: implication on occurrence and enrichment of arsenic. Environmental Earth Sciences, 75(19), 1316.

Khatib, Z., \& Salanitro, J. Reservoir souring: analysis of surveys and experience in sour waterfloods. In $S P E$ Annual Technical Conference and Exhibition, 1997: Society of Petroleum Engineers

Kumar, M., Rao, M. S., Deka, J. P., Ramanathan, A., \& Kumar, B. (2015). Integrated hydrogeochemical, isotopic and geomorphological depiction of the groundwater salinization in the aquifer system of Delhi, India. Journal of Asian Earth Sciences, 111, 936-947.

Leonard, A., \& Ward, P. (1962). Use of $\mathrm{Na} / \mathrm{Cl}$ ratios to distinguish oil-field from salt-spring brines in western Oklahoma. US Geological survey professional paper, B126-8127.

Mahmoudi, N., Nakhaei, M., \& Porhemmat, J. (2017). Assessment of hydrogeochemistry and contamination of Varamin deep aquifer, Tehran Province, Iran. Environmental Earth Sciences, 76(10), 370.

Martins, M. d. O., \& Marques, L. C. d. C. Assessment of Oilfield Souring Mechanisms by Mass Spectrometry Analysis of the Sulfur Isotopes Ratio. In International Oil Conference and Exhibition in Mexico, 2006 : Society of Petroleum Engineers

Mast, V. A. (1985). The use of ionic mixing curves in differentiating oil field brine from natural brine in a fresh water aquifer. Groundwater Monitoring \& Remediation, 5(3), 65-69.

573

574

575

576

577

578

579

580

581

582

583

584

585

586

587

588

589

590

591

592

593

594

595

596

597

598

599

600

601

602

603

604

605

606

607

608

609

610

611

612

613

614

615

616

617

618

619

620

621

622

623

624 
Matray, J., Lambert, M., \& Fontes, J. C. (1994). Stable isotope conservation and origin of saline waters from the Middle Jurassic aquifer of the Paris Basin, France. Applied Geochemistry, 9(3), 297-309.

Mirzaee, S., Chitsazan, M., Karimi, H., \& Piri, Z. (2019). Hydrochemical investigations of Sargarou spring Dehloran. journal of Advanced Applied Geology.

Panno, S., Hackley, K. C., Cartwright, K., \& Liu, C.-L. (1994). Hydrochemistry of the Mahomet Bedrock Valley Aquifer, east-central Illinois: Indicators of recharge and ground-water flow. Ground Water, 32(4), 591-605.

Richter, B., \& Kreitler, C. (1991). Identification of sources of ground-water salinization using geochemical techniques. US Environmental Protection Agency EPA. Ada, Okalahoma.

Rouhi, H., \& Kalantari, N. (2018). Hydrogeochemistry and groundwater mixing close to an oil field: an example from Asmari karstic aquifer, Khuzestan, Iran. Water Science and Technology: Water Supply, 18(2), 357-370.

Saberi, M. H. (2019). The feasibility of depositing the reservoir into hydrogen-sulfide as a result of EOR process in Cheshm-e Khosh oil field, western Iran. Arabian Journal of Geosciences, 12(2), 66.

Sarikhani, R., Dehnavi, A. G., Ahmadnejad, Z., \& Kalantari, N. (2015). Hydrochemical characteristics and groundwater quality assessment in Bushehr Province, SW Iran. Environmental Earth Sciences, 74(7), 6265-6281.

Seal, R. (2006). Sulfure isotope geochemistry of sulfide minerals. US Geological survey professional paper.

Sefie, A., Aris, A. Z., Ramli, M. F., Narany, T. S., Shamsuddin, M. K. N., Saadudin, S. B., et al. (2018). Hydrogeochemistry and groundwater quality assessment of the multilayered aquifer in Lower Kelantan Basin, Kelantan, Malaysia. Environmental earth sciences, 77(10), 397.

Sherkati, S., \& Letouzey, J. (2004). Variation of structural style and basin evolution in the central Zagros (Izeh zone and Dezful Embayment), Iran. Marine and petroleum geology, 21(5), 535-554.

Spruill, T. B. (1988). Use of Total Organic Carbon as an Indicator of Contamination from an Oil Refinery, South-Central Kansas. Groundwater Monitoring \& Remediation, 8(3), 76-82.

Teske, A., Ramsing, N. B., Habicht, K., Fukui, M., Küver, J., Jørgensen, B. B., et al. (1998). Sulfate-reducing bacteria and their activities in cyanobacterial mats of Solar Lake (Sinai, Egypt). Applied and Environmental Microbiology, 64(8), 2943-2951.

Thilagavathi, R., Chidambaram, S., Pethaperumal, S., Chivaya, S., Rao, M., Tirumales, K., et al. (2016).) An attempt to understand the behavior of dissolved organic carbon in coastal aquifers of Pandicherry region. Environmental Earth Sciences, doi:10.1007/s12665-015-48335.

Whittemore, D. O., \& Pollock, L. M. (1979). Determination of salinity sources in water resources of Kansas by minor alkali metal and halide chemistry. Available from the National Technical Information Service, Springfield VA 22161 as PB 80-128911, Price codes: A 03 in paper copy, A 01 in microfiche. Contribution(208).

Worden, R., \& Smalley, P. (1996). H2S-producing reactions in deep carbonate gas reservoirs: Khuff Formation, Abu Dhabi. Chemical Geology, 133(1-4), 157-171.

Wurbs, R. A. (2011). Water supply reliability as influenced by natural salt pollution. Journal of Contemporary Water Research and Education, 106(1), 15.

Zaporozec, A. (1972). Graphical interpretation of water quality data. Ground Water, 10(2), 32-43.

Zarei, M., Raeisi, E., Merkel, B. J., \& Kummer, N.-A. (2013). Identifying sources of salinization using hydrochemical and isotopic techniques, Konarsiah, Iran. Environmental Earth Sciences, 70(2), 587604.

Zega, M., Rožič, B., Gaberšek, M., Kanduč, T., Rožič, P. Ž., \& Verbovšek, T. (2015). Mineralogical, hydrogeochemical and isotopic characteristics of the Žveplenica sulphide karstic spring (Trebuša Valley, NW Slovenia). Environmental Earth Sciences, 74(4), 3287-3300. 
Figures

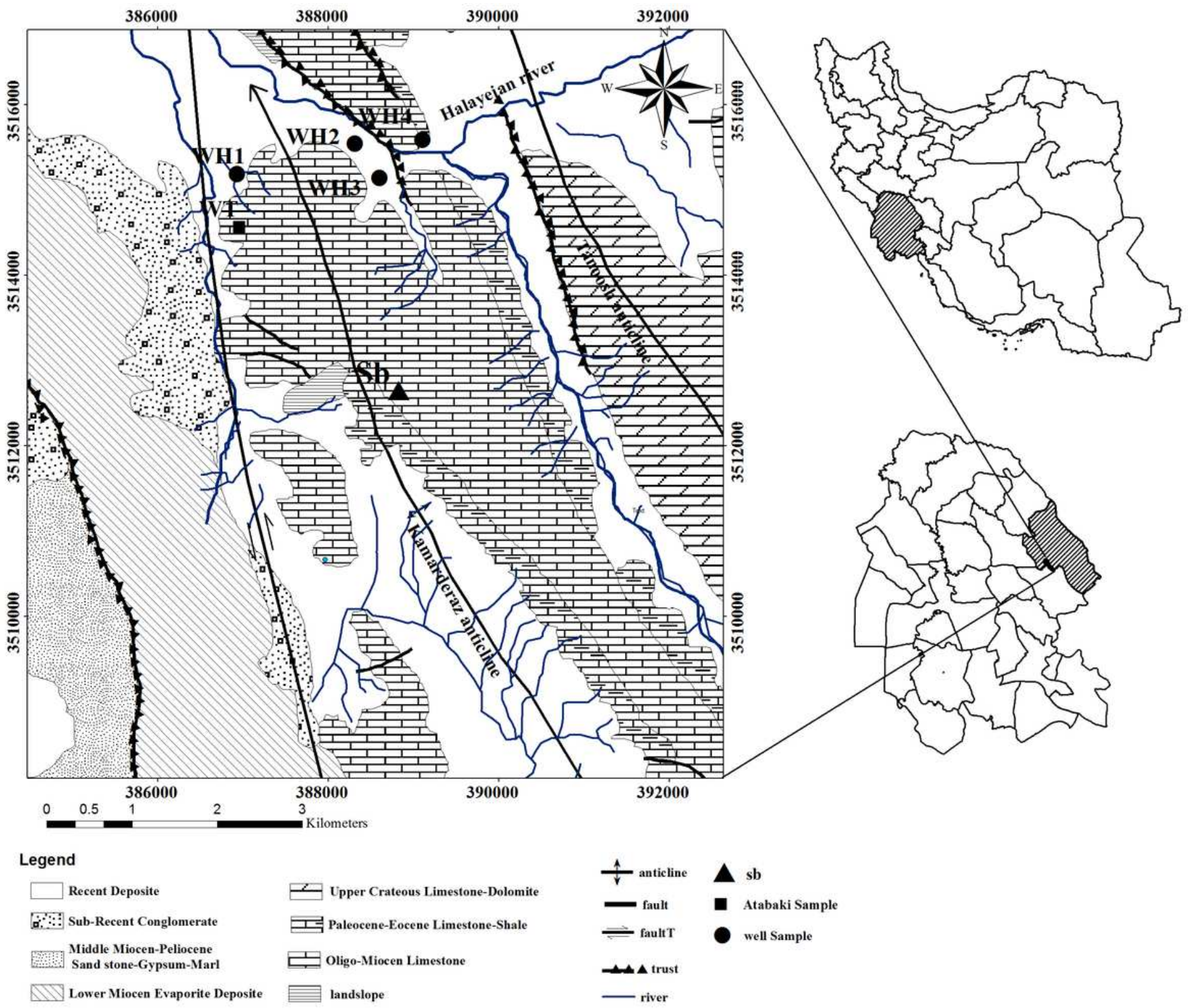

Figure 1

Location map of the study area, sampling sources and formation outcrops in the area using the 1967 Oil Company map. Note: The designations employed and the presentation of the material on this map do not imply the expression of any opinion whatsoever on the part of Research Square concerning the legal status of any country, territory, city or area or of its authorities, or concerning the delimitation of its frontiers or boundaries. This map has been provided by the authors. 


\section{Piper Diagram}

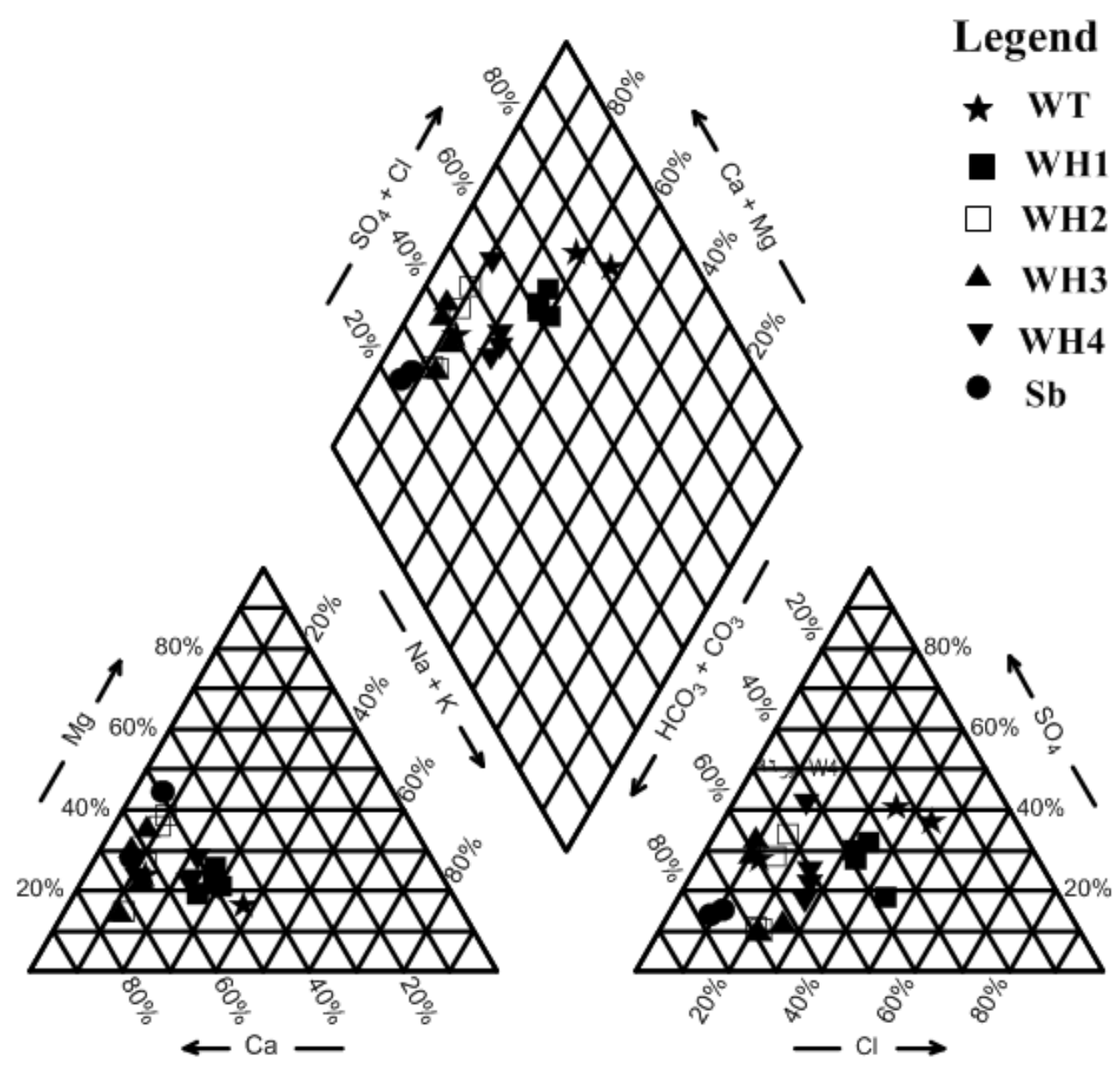

Figure 2

Representation of the studied samples in the Piper diagram 


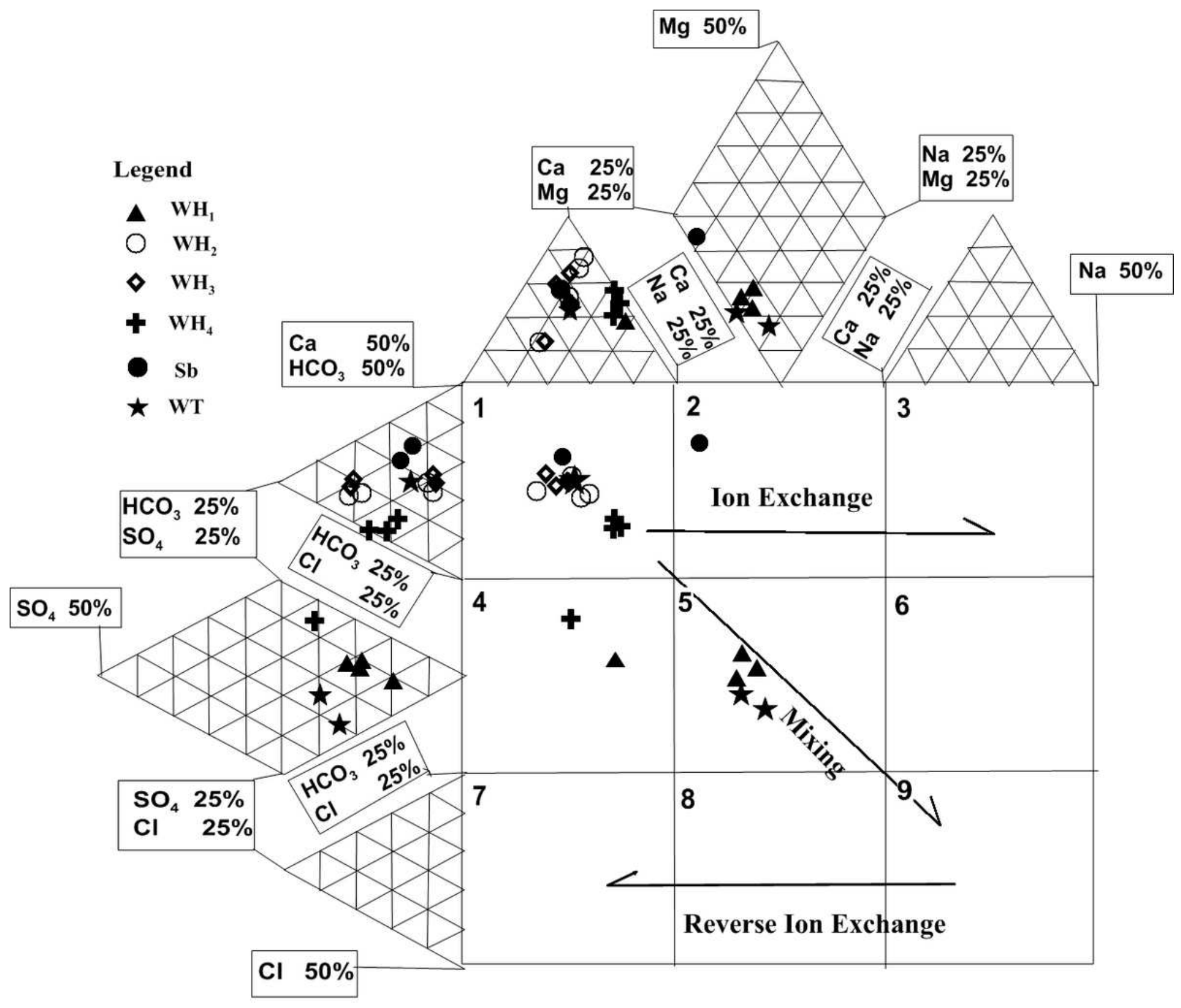

Figure 3

Representation of samples in the expanded Durov diagram 


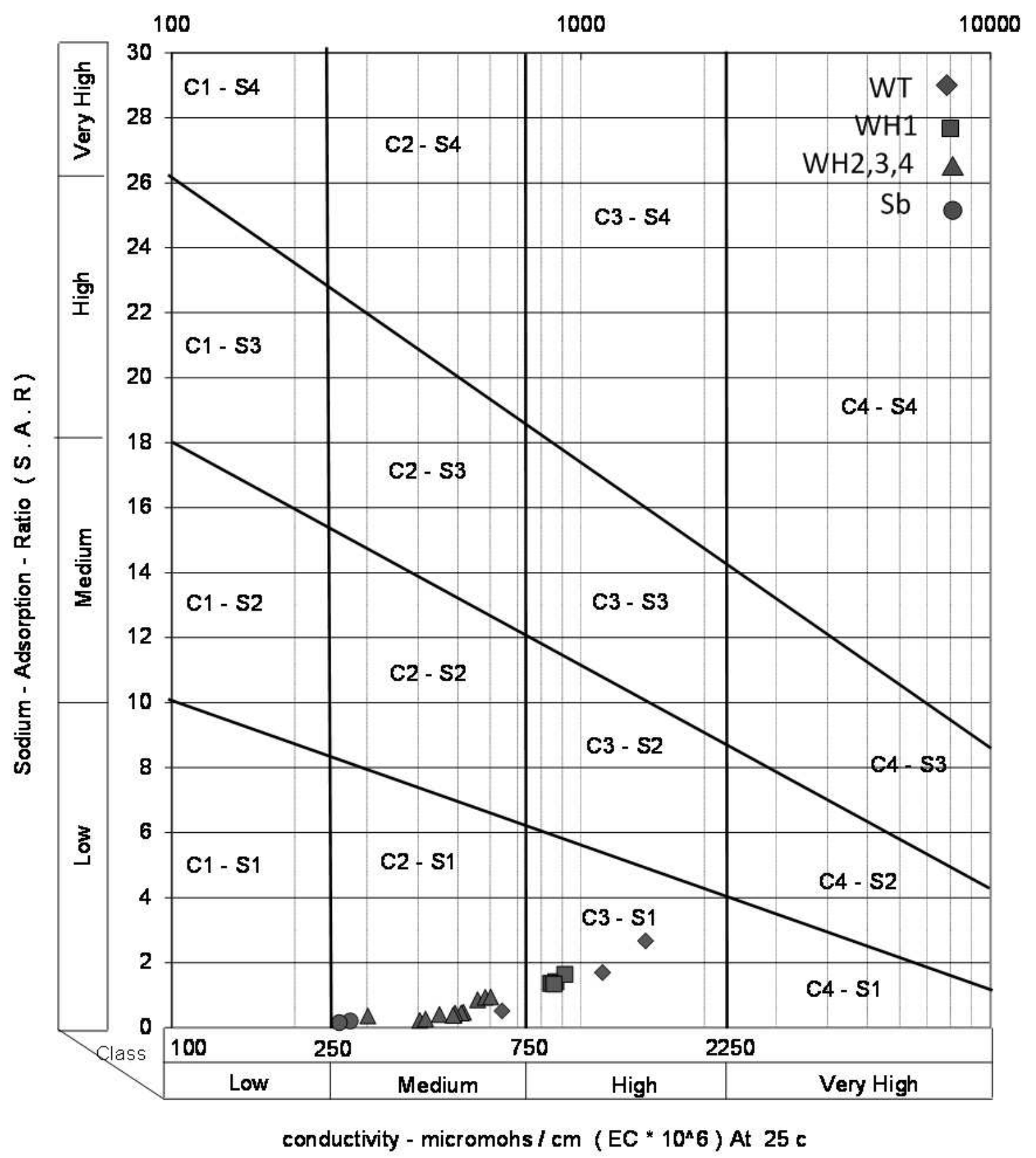

Figure 4

. Diagram of salinity risk and alkalinity of agricultural water 


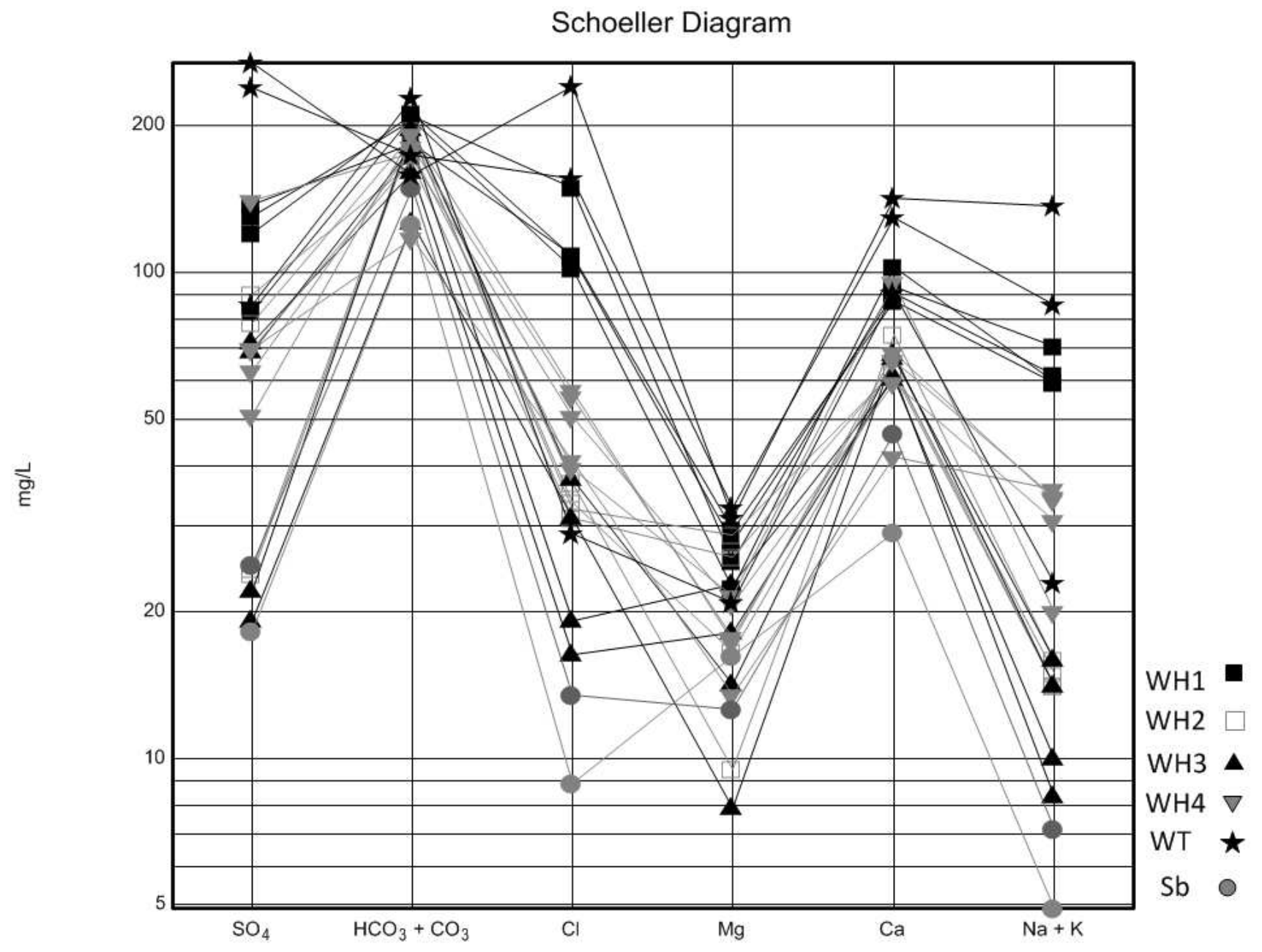

Figure 5

Schuler diagram for water samples in the study area 

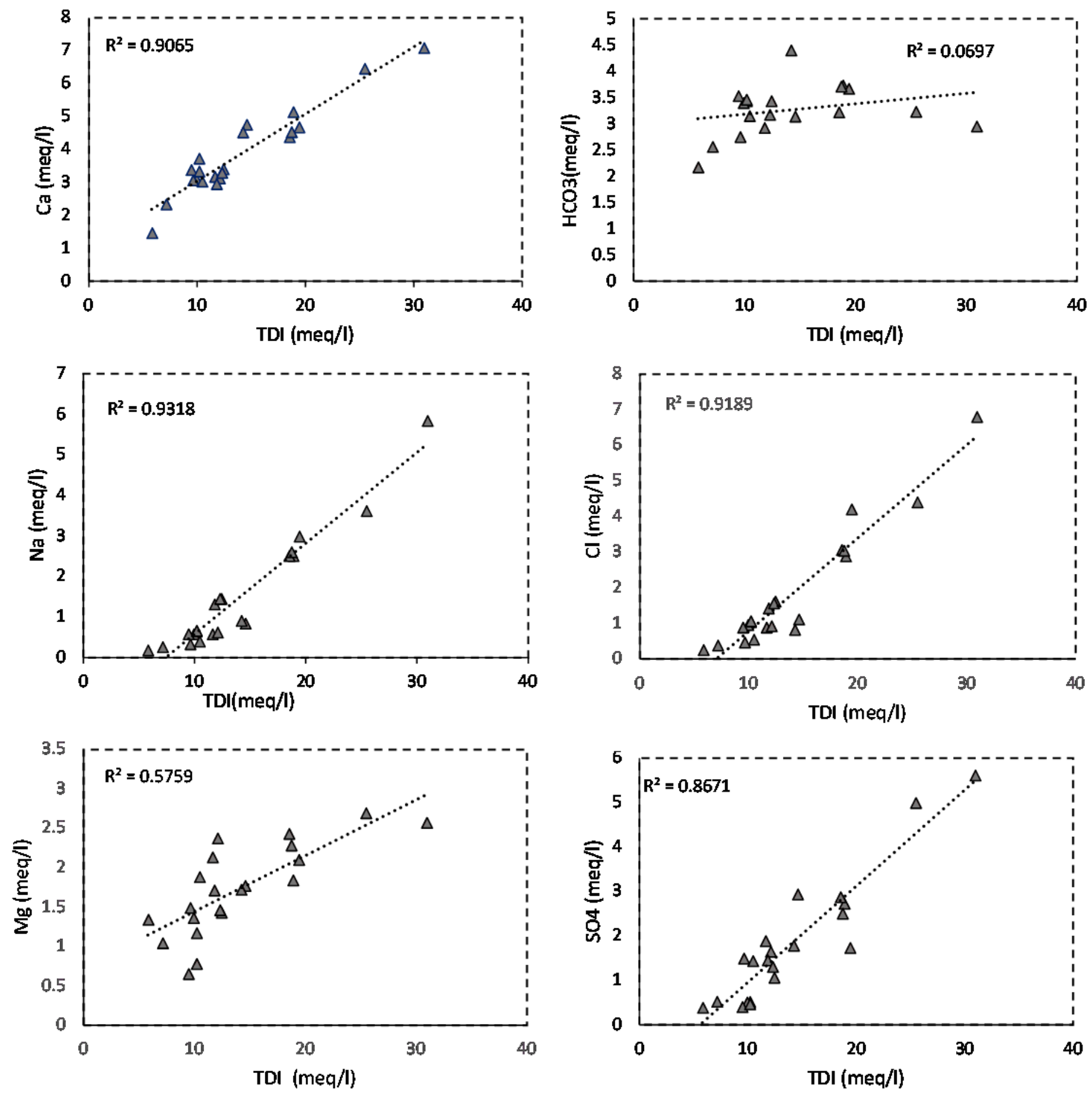

Figure 6

Composite diagrams of the major ions in the samples versus TDI 

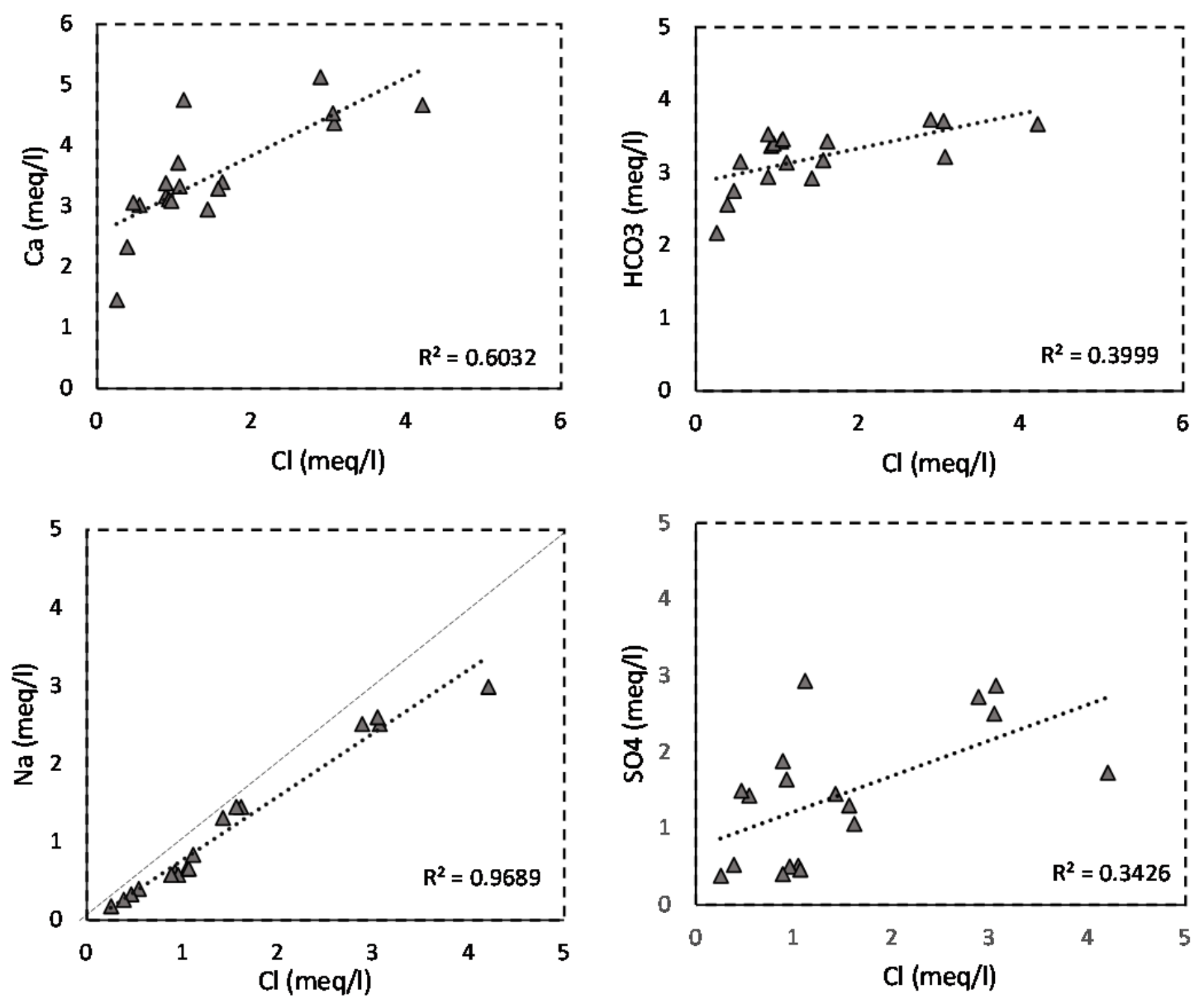

Figure 7

Composite diagram of the major ions versus the chlorine ions 


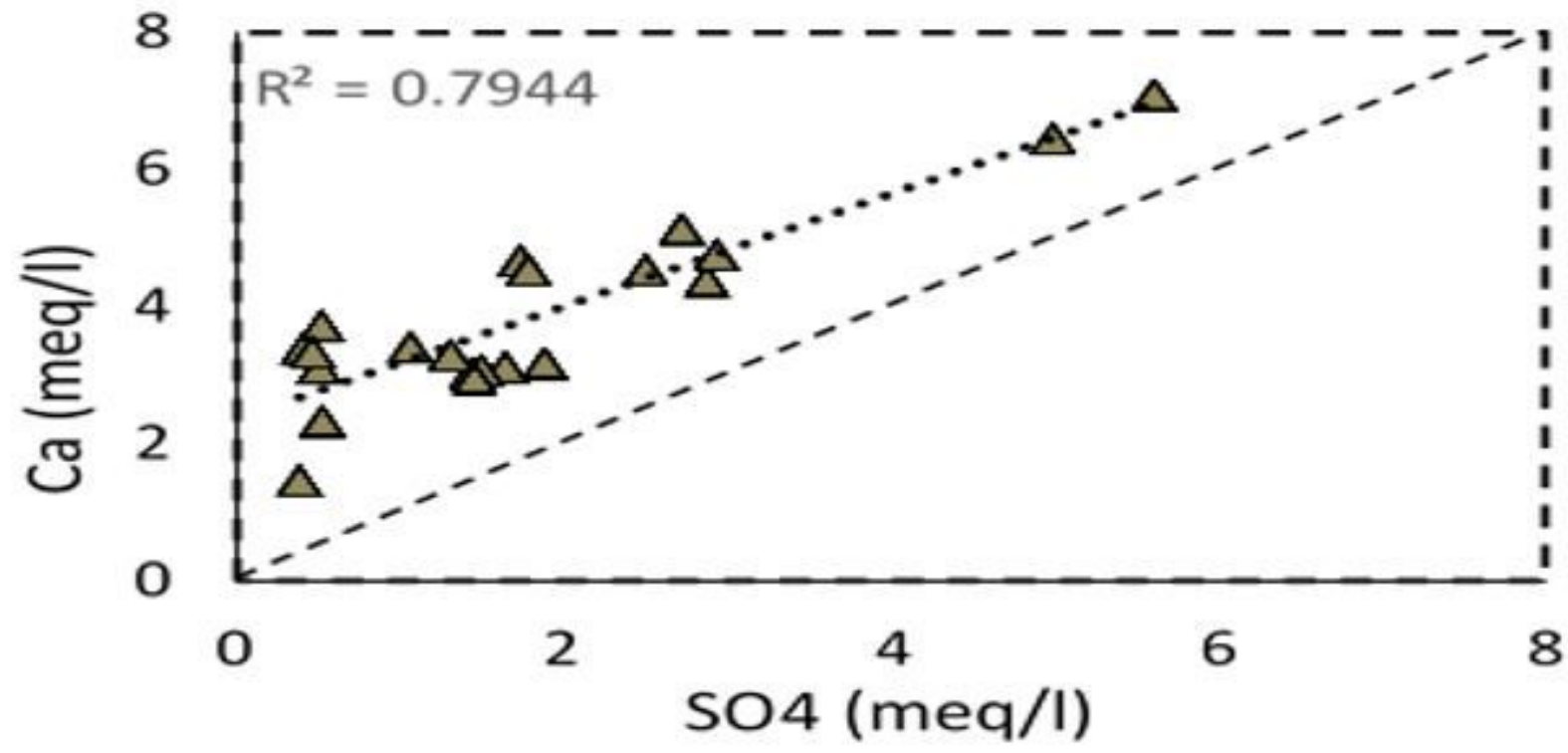

Figure 8

Composite diagram of $\mathrm{Ca} 2$ + versus $\mathrm{SO} 42$ - 


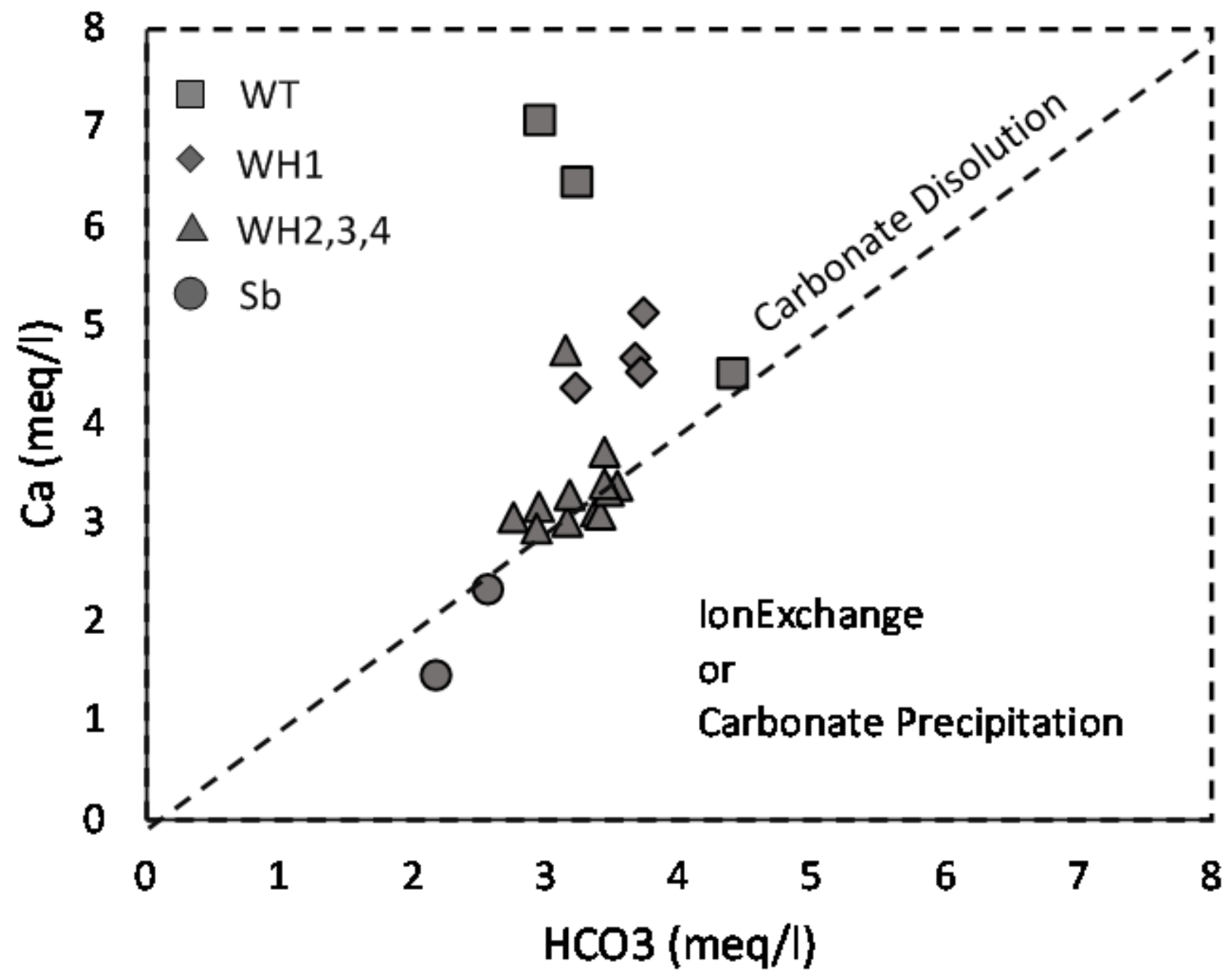

Figure 9

Ion exchange diagrams. Diagram of $\mathrm{Ca} 2+\mathrm{vs}$. $\mathrm{HCO} 32$ 


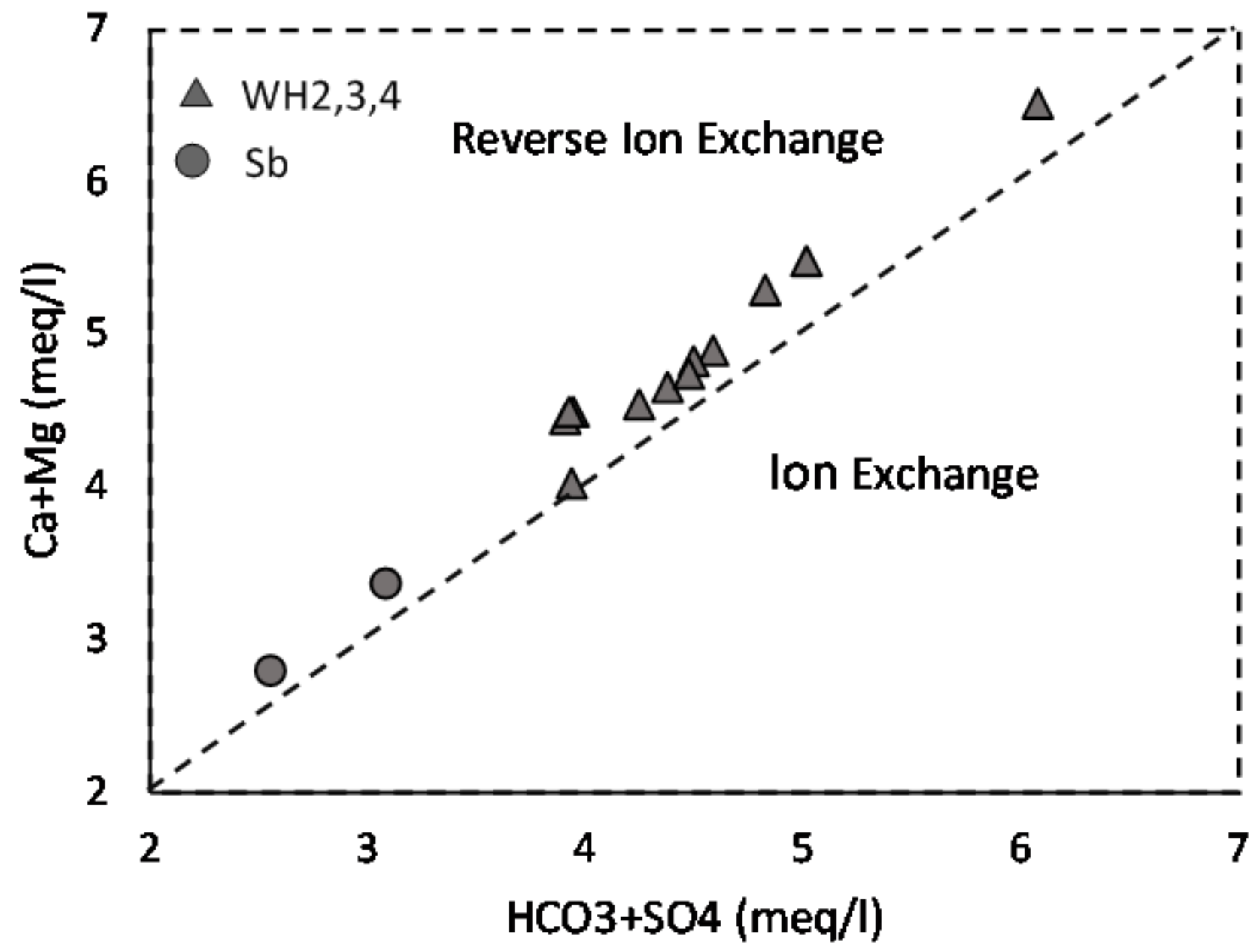

Figure 10

Diagram of $\mathrm{Ca} 2++\mathrm{Mg} 2+$ vs. $\mathrm{HCO} 32-+\mathrm{SO} 42-$ for $\mathrm{WH} 2, \mathrm{WH} 3, \mathrm{WH} 4, \mathrm{Sb}$ 


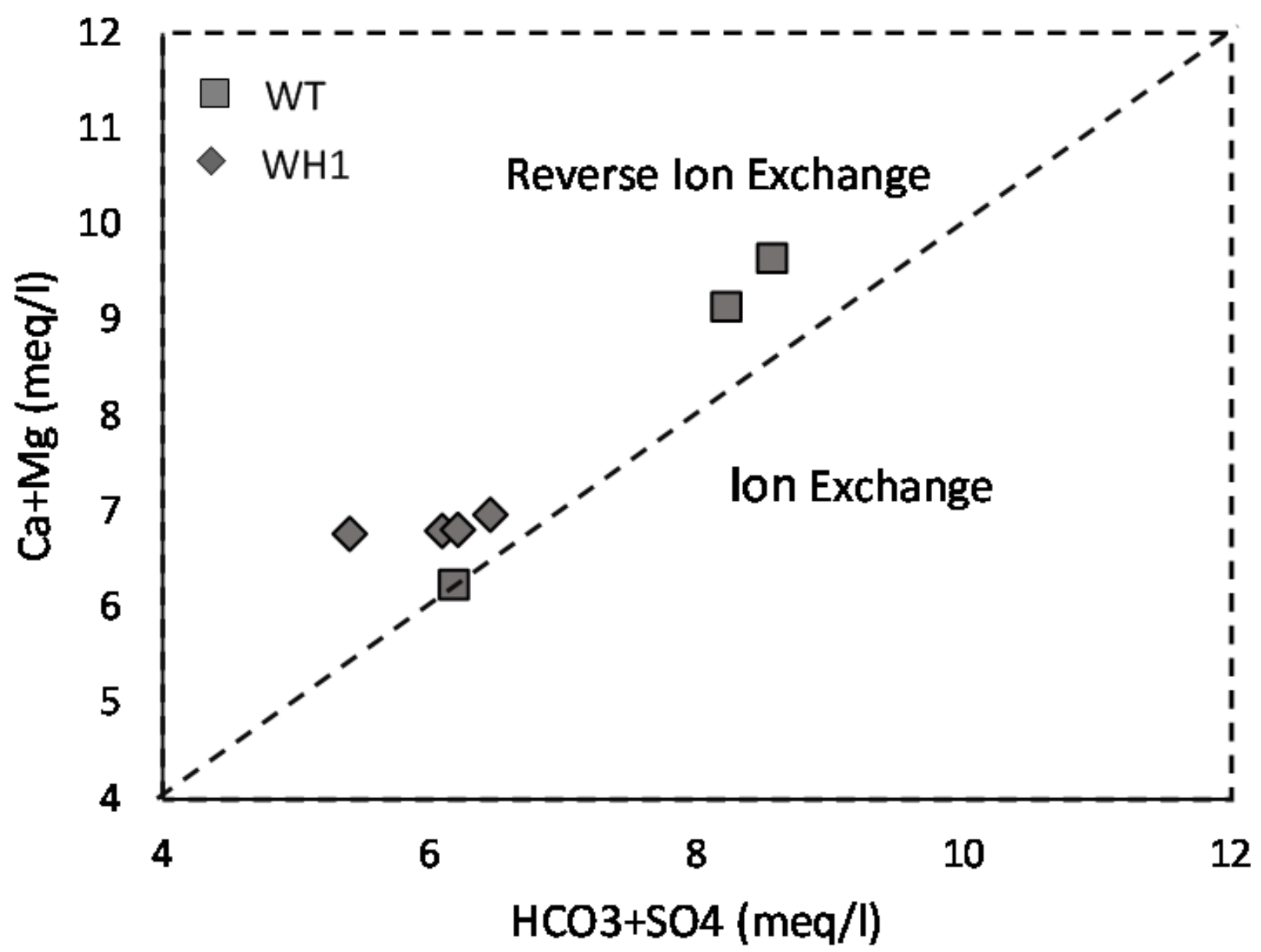

Figure 11

Diagram of $\mathrm{Ca} 2++\mathrm{Mg} 2+$ vs. HCO32- + SO42- for WH1, WT 


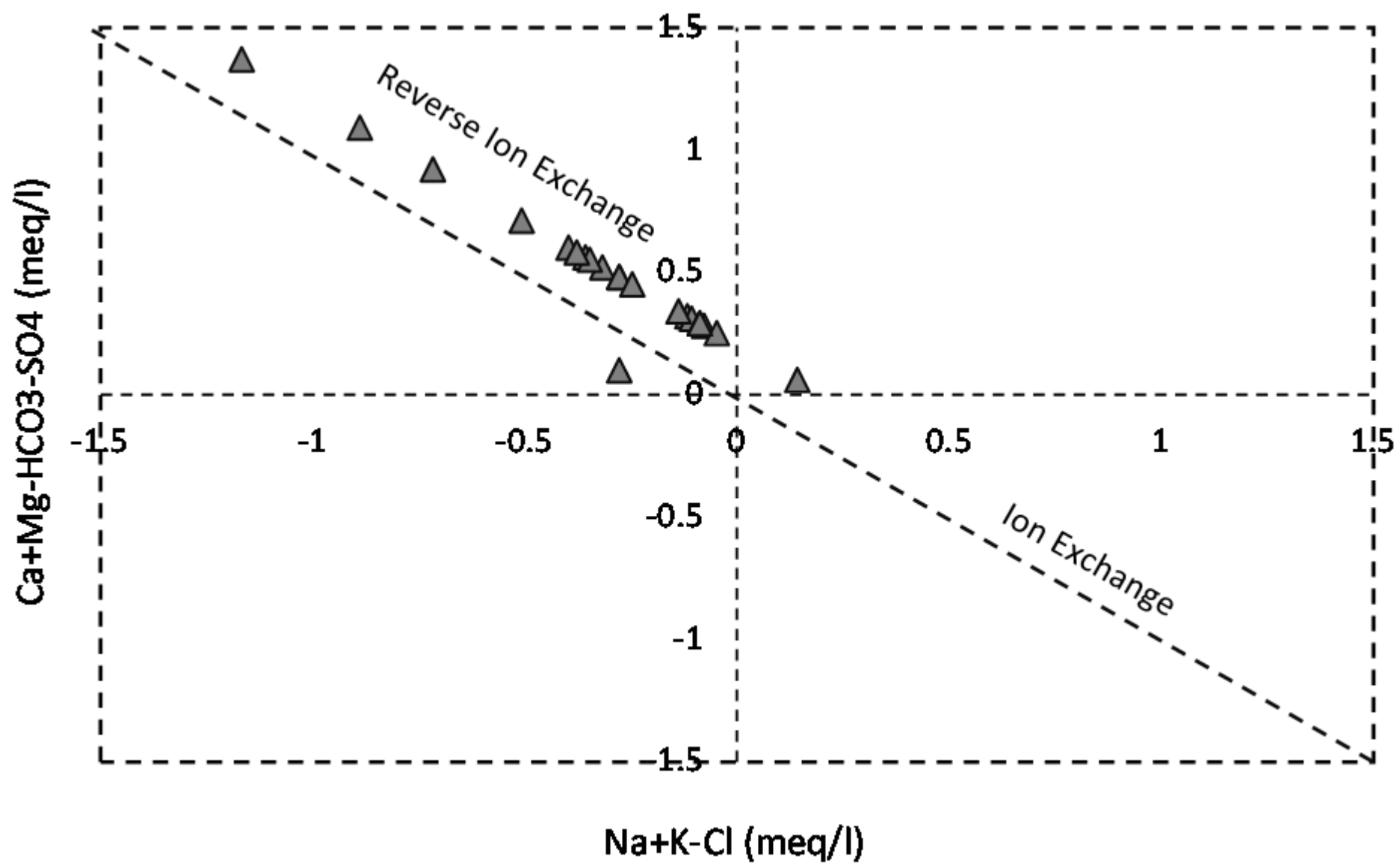

Figure 12

Diagram of $\mathrm{Na}++\mathrm{k}+-\mathrm{Cl}-\mathrm{vs}$. HCO32-+SO42- -Ca2+-Mg2+ 


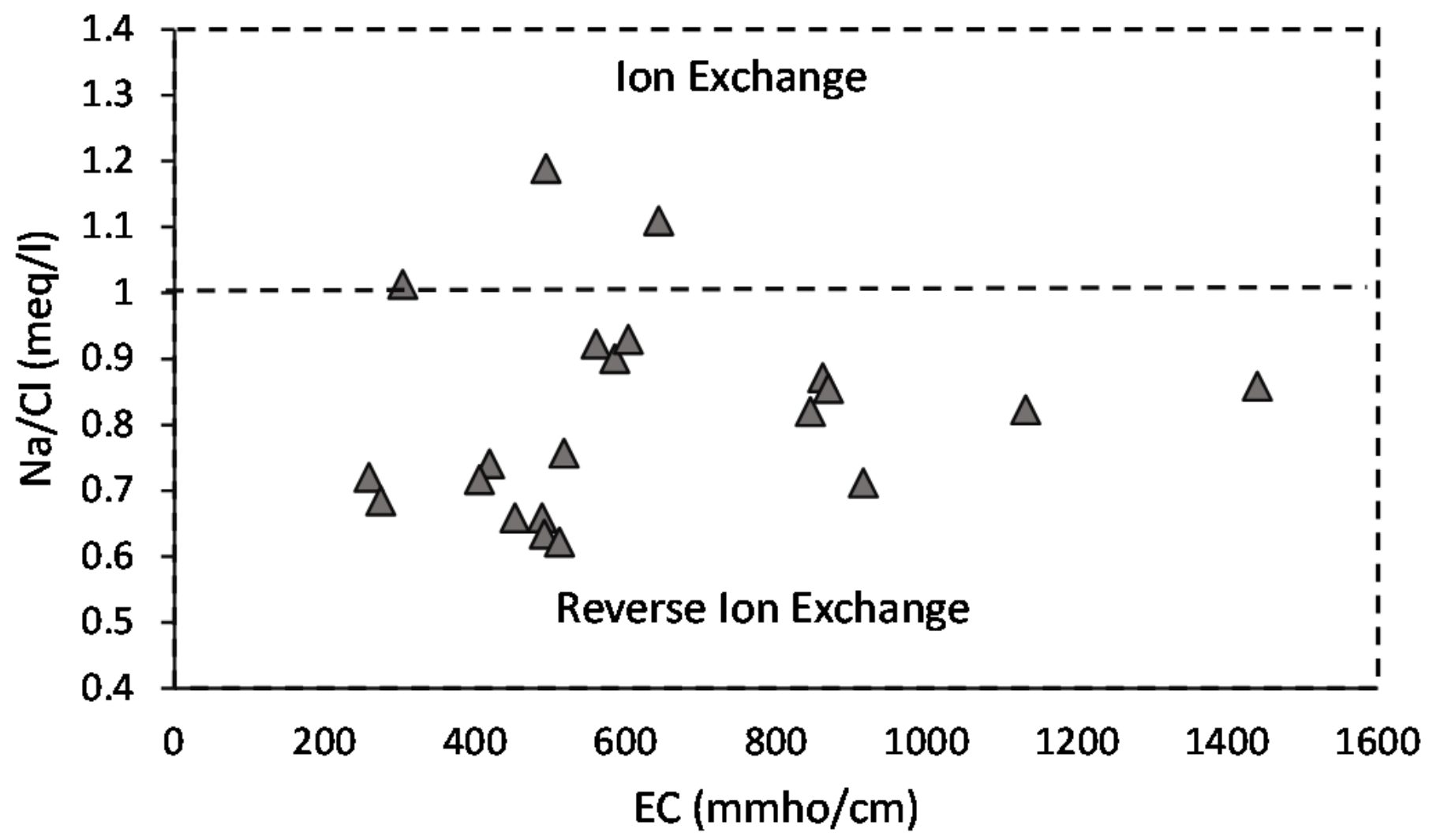

Figure 13

$\mathrm{Na} / \mathrm{Cl}$ diagram vs. EC 


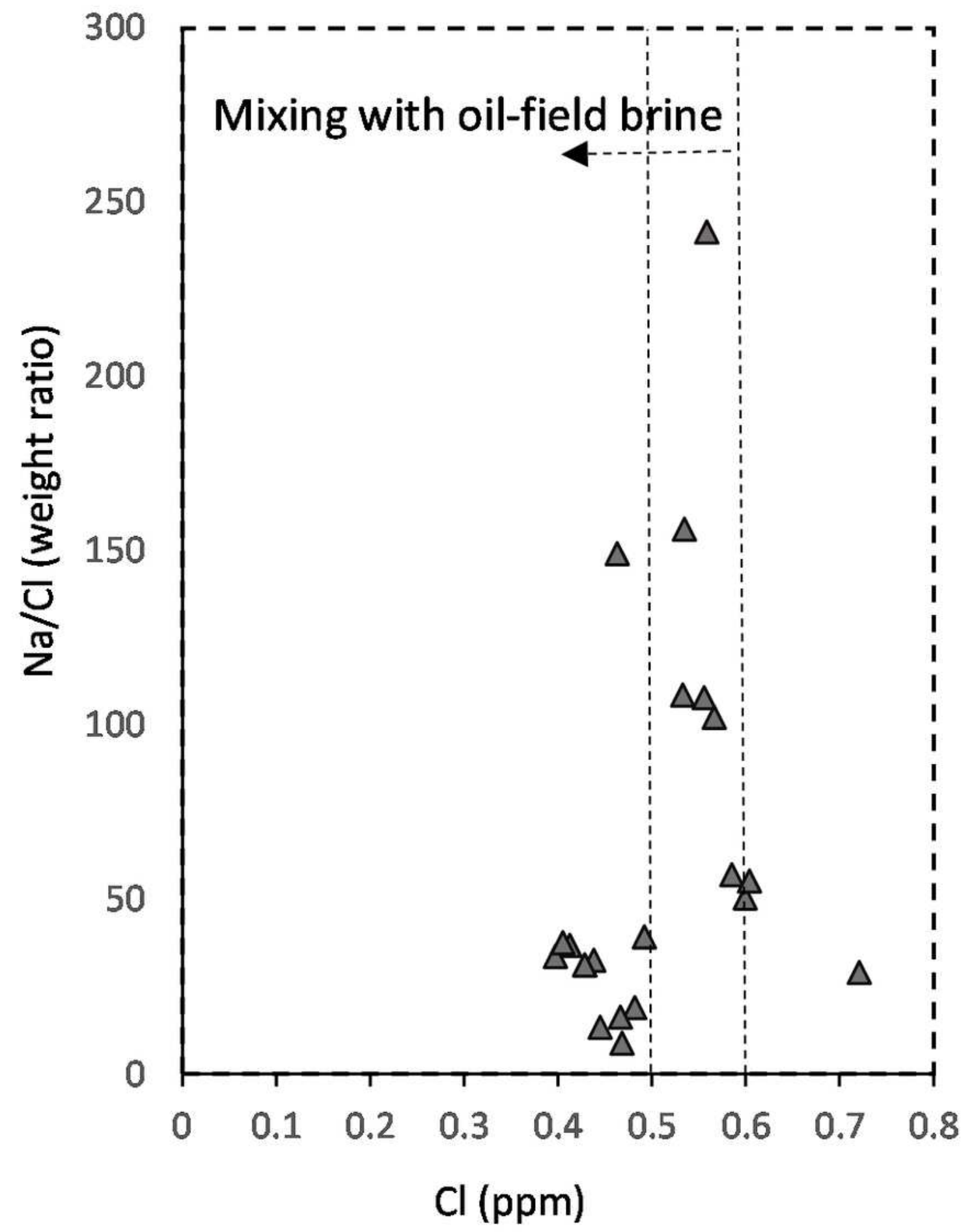

Figure 14

The graph of the $\mathrm{Na} / \mathrm{Cl}$ ratio versus $\mathrm{Cl}$ - in terms of weight ratio 


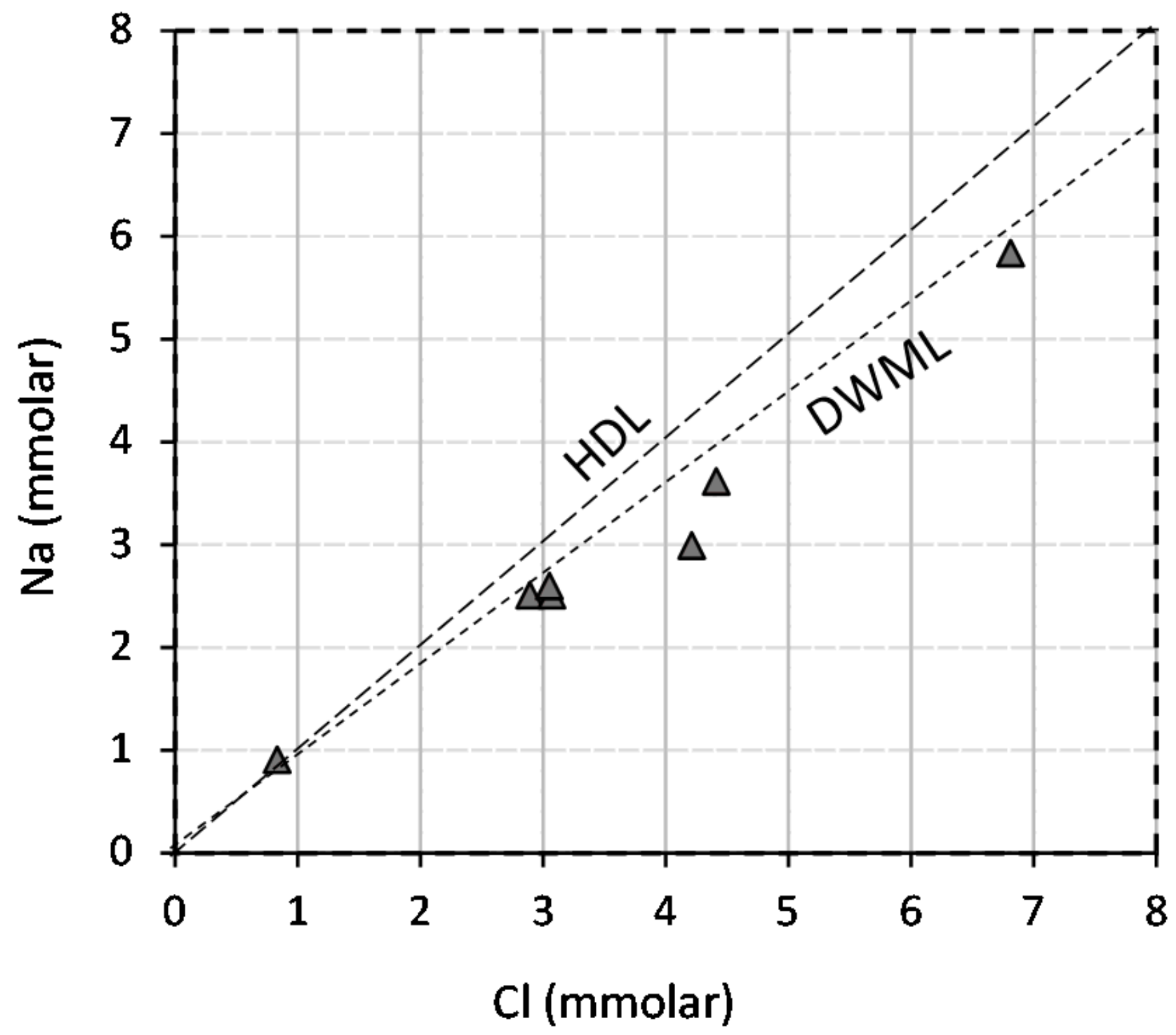

Figure 15

Diagram of $\mathrm{Na}+$ ratio to $\mathrm{Cl}$ - of WT and WH1 samples 


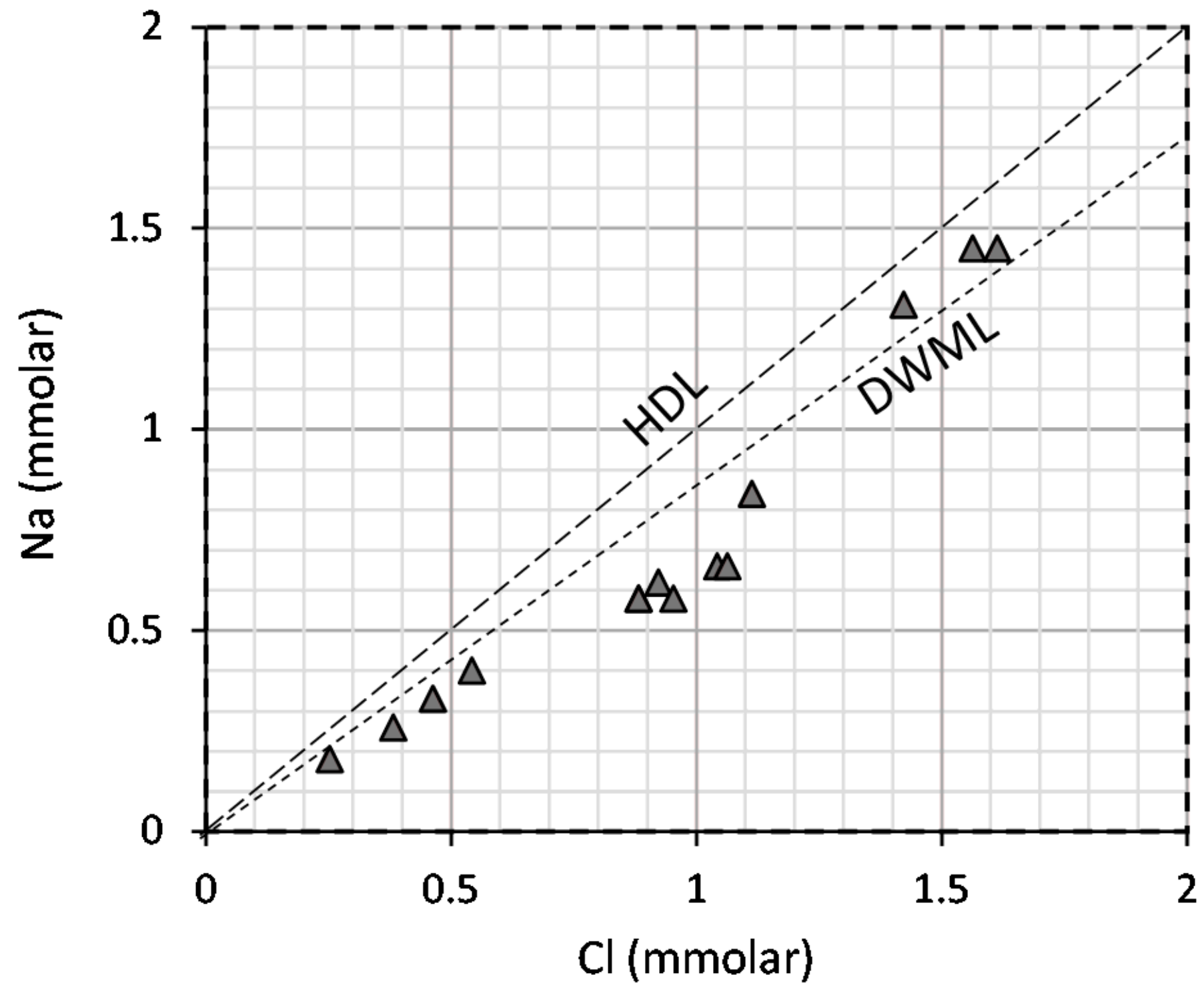

Figure 16

The graph of the $\mathrm{Na}+$ ratio to $\mathrm{Cl}$ - of samples in $\mathrm{WH} 2, \mathrm{WH} 3, \mathrm{WH} 4, \mathrm{Sb}$ 


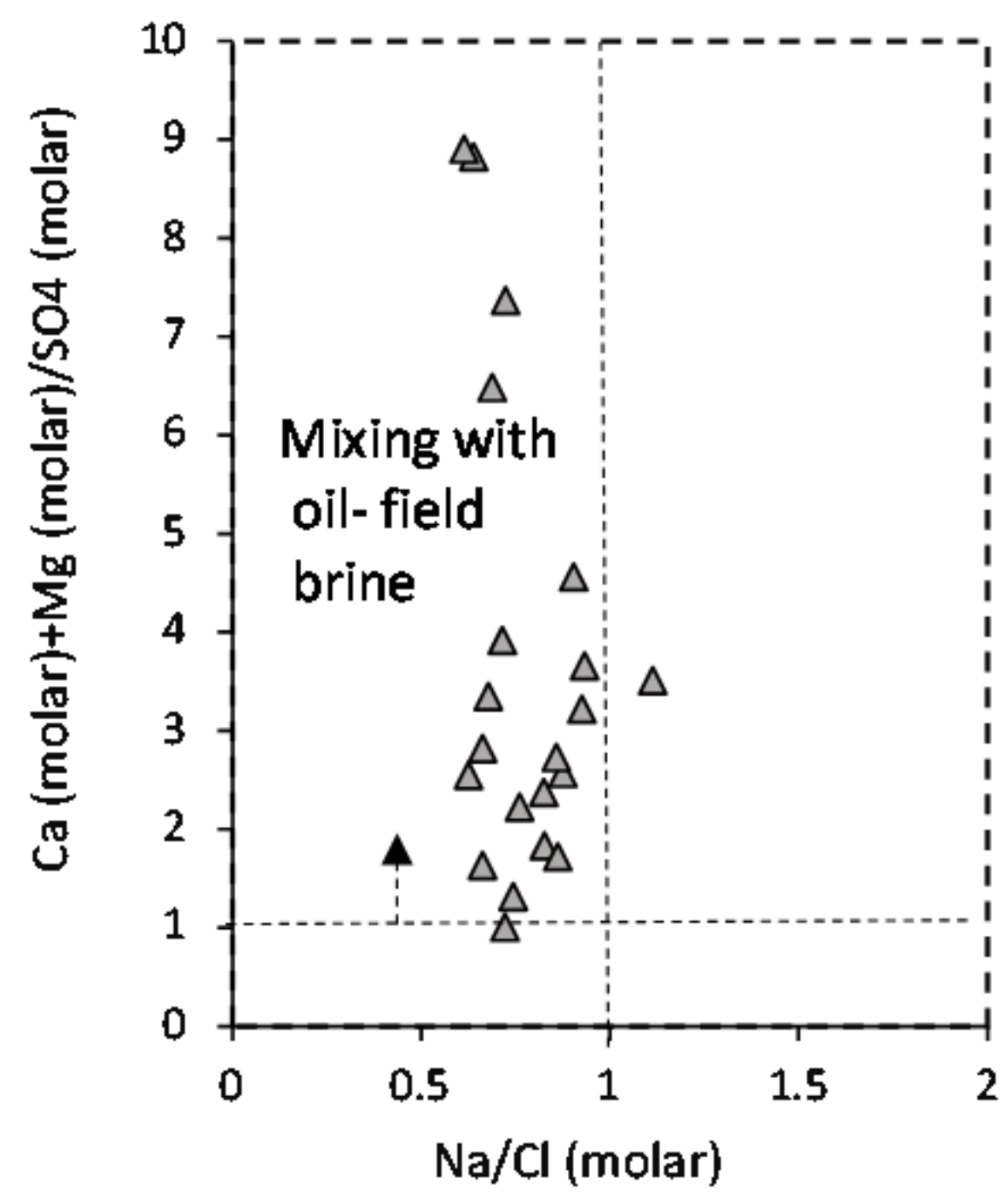

Figure 17

$(\mathrm{Ca}+\mathrm{Mg}) / \mathrm{SO} 4$ diagram vs. $\mathrm{Na} / \mathrm{Cl}$ 


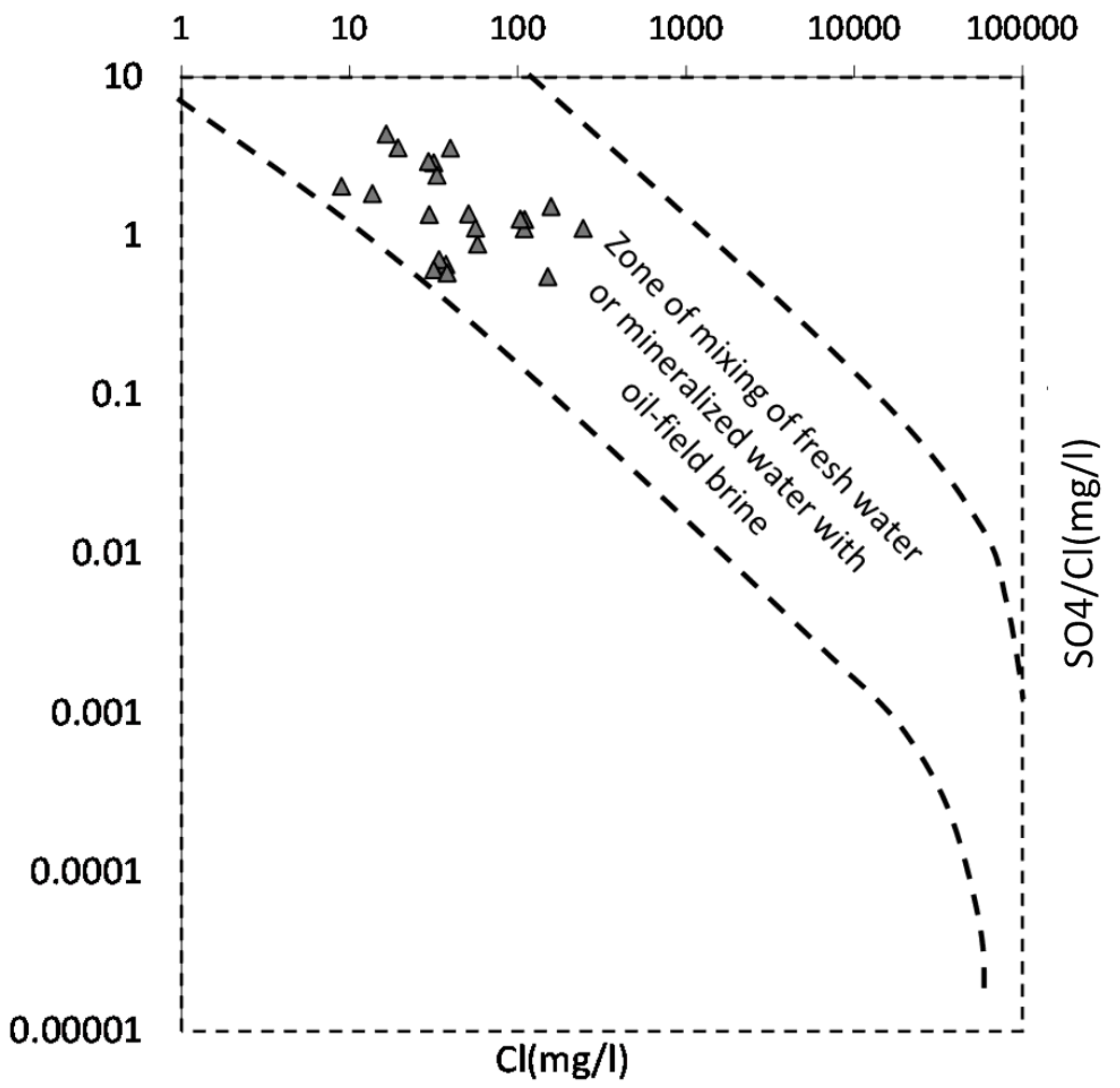

Figure 18

Diagram of the ion ratio of $\mathrm{SO} 4 / \mathrm{Cl}$ to $\mathrm{Cl}$ - in terms of weight ratio 


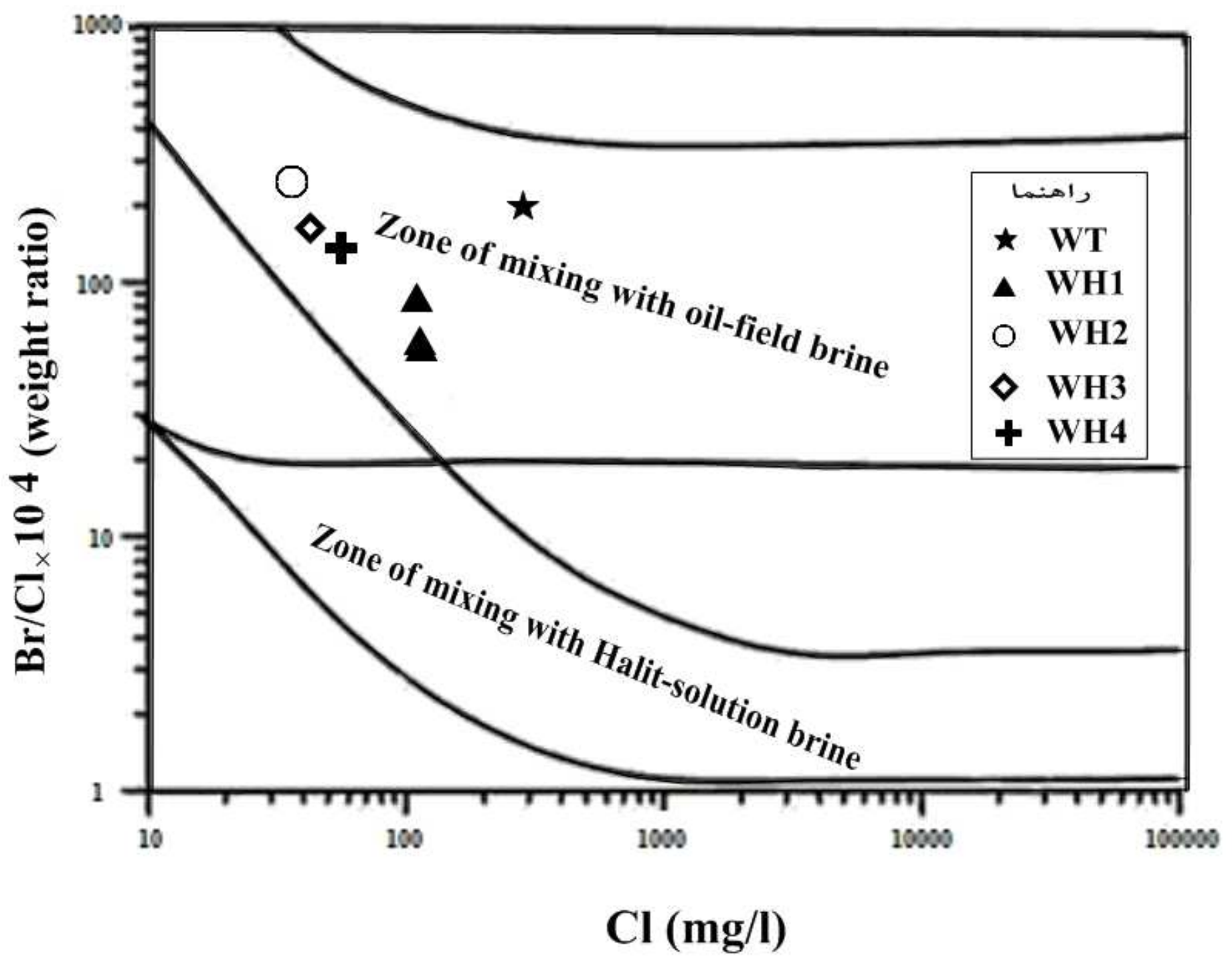

Figure 19

$\mathrm{Br} / \mathrm{Cl}$ ratio diagram versus $\mathrm{Cl}$ in weight ratio 